\title{
Formal Records and Informal Rulemaking
}

\author{
by William F. Pedersen, Jr. $†$
}

Administrative law, it is said, ${ }^{1}$ has entered an age of rulemaking. In part, the older agencies have turned to this approach of their own accord as the burden of existing responsibilities has increased. ${ }^{2}$ Far more important, Congress has spurred the trend by creating new agencies with new responsibilities. These agencies could not possibly discharge their sweeping mandates to regulate pollution, ${ }^{3}$ energy, ${ }^{4}$ occupational health and safety, ${ }^{5}$ coal mine safety ${ }^{6}$ and consumer product safety (to give only a few examples) through case-by-case adjudication in formal hearings. But Congress has not trusted nature to see to it that rulemaking rather than adjudication is chosen. In many cases, the regulatory statute explicitly provides that standards shall be set by rulemaking, though procedural protections exceeding the minimum required by due process or the Administrative Procedure Act (APA) ${ }^{\mathrm{s}}$ may frequently be specified. ${ }^{9}$

The increased use of rulemaking has changed the whole structure

+ Attorney, Office of General Counsel, Environmental Protection Agency.

The views expressed in this article are those of the author only and not necessarily those of the Environmental Protection Agency or of any other employee of the Environmental Protection Agency.

However, I would like to express my appreciation to my colleagues in the EPA General Counsel's office for their assistance, and in particular to John E. Bonine, Richard J. Denney, and Gerald K. Gleason for the thoughts which they contributed.

1. Most forcibly in Wright, The Courts and the Rulemaking Process: The Limils of Judicial Review, 59 CoRNell L. REv. 375 (1974), an atticle to which this one is much indebted.

2. See Permian Basin Area Rate Cases, 390 U.S. 747, 756-58 (1968); National l'etrolem Ref. Ass'n v. FTC, 482 F.2d 672, 690-91 (D.C. Cir. 1973), cert. denied, 415 U.S. 951 (1974).

3. See Reorganization Plan No. 3 of 1970, 35 Fed. Reg. 15623, 81 Stat. 2086, which became effective on Dec. 2, 1970, pursuant to 5 U.S.C. $\$ 906$ (1970) (creation of the Environmental Protection Agency).

4. See 15 U.S.C.A. $\$ \$ 761-86$ (Supp. 1975) (creation of the Federal Encrgy Idministration); Energy Reorganization Act of 1974, Pub. L. No. 93.438, 88 Stat. 1233 (creatiun of the Energy Research and Development Administration).

5. See 29 U.S.C. $\$ \$ 651.78$ (Supp. III 1973) (granting regulatory powers to the Secretary of Labor, which led to the creation of the Occupational Safety and Health Administration). See also 29 C.F.R. $\$ \$ 1901.01-1999.8$ (1974).

6. The responsibility for more stringent coal mine safety standards is divided among several agencies. See 30 U.S.C. $\$ \$ 801-960$ (Supp. III 1973),

7. See 15 U.S.C. $\$ \$ 2051-81$ (Supp. III 1973) (creation of the Consumer Product Safety Commission).

8. 5 U.S.C. $\$ \S 551-706$ (Supp. III 1973).

9. See Hamilton, Procedures for the Adoption of Rules of General Applicability: The Need for Procedural Innovation in Rulemaking, 60 CAL. L. REv. 1276, 1315-26 (1972). 
of administrative law, for as recently as the early 1960's it was generally assumed that any significant regulatory scheme would rely to a considerable extent on trial-type hearings. ${ }^{10}$ The shift to rulemaking has been urged and supported both by commentators and to a surprising extent by the courts.11

The procedures used in rulemaking have not kept pace with these developments. At present, they provide neither a satisfactory framework for agency decisionmaking nor a structure to those decisions that would ease judicial review. These weaknesses of the current approach stem largely from a failure to specify and limit the record on the basis of which rules are promulgated. If rules, like formal adjudications, were based on clearly defined records, the efficiency of both rulemaking and judicial review would be increased. Rulemaking procedures should provide for compiling and organizing an administrative record while rulemaking is in process, with use of a discovery system to ensure that no material which properly should be included is left out.

These reforms have been suggested to me by my experience during the last few years as a lawyer at the Environmental Protection Agency, and much of the discussion concerns EPA specifically.

\section{The Rulemaking Framework}

\section{A. The Expanded Scope of Rulemaking}

Section 551 of the Administrative Procedure Act divides the agency actions of interest here into the two categories of "orders"12 and

10. This, for example, is the clear assumption of Professor Davis throughout the original four volumes of his Administrative Law Treatise, which were published in 1958. Two other books published during the same period share the assumption that formal adjudication will continue to be the mainstay of administrative action. See $L$. Jaffe, Judicial Control of Administrative Action (1965); H. Friendly, The Federal Administrative Agencies: The Need for Better Definition of Standards (1962).

11. See National Nutritional Foods Ass'n v. Weinberger, 512 F.2d 688, 698 (2d Cir. 1975) ("over the last decade rule-making has been increasingly substituted for adjudication as a regulatory technique, with the support and encouragement of courts, at least where the regulation involves specialized scientific knowledge"); National Petroleum Ref. Ass'n v. FTC, 482 F.2d 672, 681-84 (D.C. Cir. 1973); American Airlines, Inc. v. CAB, 359 F.2d 624, 630-31 (D.C. Cir.) (Leventhal, J.), cert. denied, 385 U.S. 843 (1966); 1 K. Davis, Administrative Law Treatise $\$ \S 6.15,6.18$ (Supp. 1970); K. Davis, Discretionary JUSTICE $65-68$ (1969); H. FRIENDLY, supra note 10, at 142-46; Shapiro, The Choice of Rulemaking or Adjudication in the Development of Administrative Policy, 78 HARv. L. REv. 921, 922 \& n.I (1965). See also Recommendation 72.5 of the Administrative Conference of the United States, 1 C.F.R. $\$ 305.72-5$ (1975) (adopted Dec. 14, 1972).

12. An "order" is "the whole or a part of a final disposition, whether affirmative, negative, injunctive or declaratory in form, of an agency in a matter other than rule making." 5 U.S.C. $\$ 551(6)$ (Supp. III 1973).

One might argue from the text of these definitions that anything an agency does which is "final" and is not rulemaking must be adjudication. This is supported by 
"rules."13 The two most common types of agency proceedings, producing orders and rules respectively, are known as formal adjudication and informal rulemaking. ${ }^{14}$

Formal adjudication involves a quasi-judicial hearing before an administrative law judge; ${ }^{15}$ witnesses appear for both sides and are usu-

statements in the AP.A's legislative history that 5 U.S.C. 551 (12), which defines "agency proceeding" to include all forms of rulemaking and adjudication, was meant to "assure that all forms of administrative procedure or authority are included." SENATE JUdiciarX Comm., Administrative Procedure Act: Legislative History, S. Doc. No. 248, 79th Cong., 2d Sess. 255 (1946) (quoting from report of the House Judiciary Comm.); S. Doc. No. 248, supra at $197-98$ (quoting from report of the Senate Judiciary Comm.).

On the other hand, "agency action" is defined by $\$ 551(13)$ in even broader terms than those used to describe "agency proceeding," and is the subject of even more expansive language in the legislative history. S. Doc. No. 248, supra at 198, 255. The .1PA provides for judicial review of any "final agency action," 5 U.S.C. $\$ 704$ (Supp. III 1973), and this language has been read by Judge Friendly to authorize judicial review of an "action" which he apparently regarded as neither a "rule" nor an "order." See United States $c *$ rel. Schonbrun v. Commanding Officer, 403 F.2d 371, 375 n.2 (2d Cir. 1968), cert. denied, 394 U.S. 929 (1969).

The question is largely if not entirely semantic, howerer, siuce the only way the two terms "rulemaking" and "adjudication" can be made to account for all "final" agency actions is by hypothesizing a residual category of "informal adjudication" (iec note lit infra) which is not rulemaking and not subject to the formal adjudicatory hearing requirements of 5 U.S.C. $\$ \$ 554,556$ and 557 . The Administrative Procedure Act lays down no separate rules for "informal adjudications," and so the presence or absence of that label has no operational effect.

The Supreme Court has recently reconfirmed that agency actions which are not "final," but which represent an intermediate stage in a chain of events that may culminate in a more formal proceeding, are not subject to the requirements of the APA. See ITT $\mathrm{v}$. Local 134, IBEW, 419 U.S. 428, 442-44 (1975).

13. A "rule" is "the whole or a part of an agency statement of general or particular applicability and future effect designed to implement, interpret, or prescribe law or policy." 5 U.S.C. $\$ 551(4)$ (Supp. III 1973).

14. Both rulemaking and adjudication can be either "formal" or "informal." As a practical matter, however, "formal" rulemaking is rarely called for, while "informal" adjudication is a catchall category covering a multitude of "final" agency decisions which do not fit anywhere else and which have no common theme or pattern.

Agencies take a great many actions by means which often do not meet even the standard of formality established for informal rulemaking. Some examples would be the decision to issue a complaint, start an investigation, fund a highway, order a drug label changed, or write an environmental impact statement. Professor Davis has estimated that up to 80 or 90 percent of agency actions may fall in this category. 1 K. Davis, Administrative Law Trastise $\$ 4.13$, at 206 (Supp. 1970). Since these actions may or may not be "final," they would not necessarily be classificd as "informal adjudications" under the approach outlined in note 12 above, because only a "final" action can be any kind of an "adjudication" within the meaning of the Al. 1 . Nevertheless, according to Professor" Davis, "the ratio of informal adjudication to formal may be fifty or a hundred to one." K. DAvis, Discrerionary Justice 21 (1969). However, he regards actions which are not final at all-interim decisions on "initiating, investigating, prosecuting, negotiating, settling, contracting, dealing, advising, threatening, publicizing, concealing, planning, recommending. supervising"-as more important still. Id. at 22. Such actions individually and collectively may be of great importance and have been the focus of increasing attention by courts and legal scholars in recent years. But recognition of them does not diminish the tremendous significance of formal adjudication and informal rulemaking.

15. The original Administrative Procedure tct established a class of government employees called "hearing examiners" who would preside in formal administrative hearings. Although they are assigned to individual agencies, their tenure and promotion are 
ally cross-examined extensively, generating a record in the familiar courtroom manner.16 The statutory requirements for informal rulemaking; by contrast, are limited. The agency must publish in the Federal Register"17 "the terms or substance of the proposed rule or a description of the subjects and issues involved,"1s receive comments from "interested persons," and publish the final regulations, incorporating a "concise general statement of their basis and purpose."19 The APA does not make these minimum procedures exclusive, ${ }^{20}$ and does not attempt to define a record for agency decision.

Many agency decisions fit under the APA definitions of both "rules" and "orders" and therefore could legitimately be made either through informal rulemaking or through adjudication. Where both approaches are authorized by the particular regulatory statute and either is constitutionally permissible, the choice between them is in large part left to the agency. ${ }^{11}$ Recently, the range of cases in which an agency may choose rulemaking instead of adjudication has been greatly broadened.

The traditional view was that the constitutional right of a regulated party to an adjudicatory hearing turned on the type of administrative action in question. For over 60 years it has been established that some administrative actions which verge on the "ju-

within the sole control of the Civil Service Commission as a protection against pressure. See 5 U.S.C. $\$ \$ 556(\mathrm{~b}), 3105,5362,7521$ (Supp. III 1973). The title of these officials was changed to "Idministrative Law Judge" by regulation in 1972. See 5 C.F.R. $\$ \$ 930.201$ 030.215 (1974), incorporating amendments from $37 \mathrm{Fcd}$. Rcg. 16787 (1972). This change in title does not denote any alteration of their functions.

16. With some variations, this is also the procedure used for "formal" rulemaking.

17. 5 U.S.C. $\$ 553(b)$ (Supp. III 1973). Service of notice on the affected parties may be substituted for publication. Id.

18. 5 U.S.C. $\$ 553($ b)(3) (Supp. III 1973).

19. 5 U.S.C. \$ 553(c) (Supp. III 1973).

20. For this reason, the proposals that will follow could be partially adopted by unilateral action within the agencies. But since procedural reform has an understandably low priority in the most active agencies, and since it is also necessary to make the reforms bind others besides the agency, these proposals should be considered primarily as suggestions for Iegislative action. The suggested procedural reforms could, however, also be required by the courts. In recent years the D.C. Circuit, at least, has been very free in establishing new procedural requirements for informal rulemaking, generally in the exercise of a supervisory power over the agencies which it has grounded only loosely, if at all, in any specific statutory or constitutional provisions. Thus, in Kennecott Copper Corp. v. E.A, 462 F.2d 846, 850 (D.C. Cir. 1972), Judge Leventhal required a more detailed statement of the basis and purpose of the regulations in "the interest of justice ... and in aid of the judicial function" of review. In Portland Cement Ass'n v. Ruckelshaus, 486 F.2d 375, 393 (D.C. Cir. 1973), cert. denied, 417 U.S. 921 (1974), he simply said that it was "not consonant with the purpose of a rule-making proceeding" to base rules on inadequate or undisclosed data. See Wright, supra note 1, at $381-88$ (acknowledgment and criticism of this trend).

21. "[T]he choice made between procecding by general rule or by individual, ad hoc litigation is one that lies primarily in the informed discretion of the administrative agency." SEC v. Chenery Corp., 332 U.S. 194, 203 (1947) (Chenery II). "[T]he choice between rulemaking and adjudication lies in the first instance within the [administrative agency's] discretion." NLRB v. Bell Aerospace Co., 416 U.S. 267, 294 (1974). 
dicial" cannot constitutionally be taken without offering an adjudicatory hearing to those affected. Where this type of action is federal, the formal hearing requirements of the Administrative Procedure Act probably apply. ${ }^{22}$ But in cases involving administrative actions which seem more "legislative," there has been no such hearing requirement..23 In recent years, the notion that the availability of an adjudicatory hearing should depend solely on whether the action the agency is taking has a legislative, future-oriented character has for the most part, in Judge Friendly's phrase, "gone to a deserved repose." tests have been debated, turning alternatively on the kinds of facts at issue, the sorts of rights involved, the number of people affected, or the administrative scheme at issue and what it can tolerate. ${ }^{25}$

During the past decade, the courts have used the latitude left them by the number and unsettled priority of these tests to pare down any right to an adjudicatory hearing in complicated regulatory programs. ${ }^{20}$

22. Wong Yang Sung v. McGrath, 339 U.S. 33 (1950) (APA held applicable to deportation proceedings conducted by the Immigration Service). Wong Yang Sung has not always been followed, but it was cited with approval in ITT v. Local 134, IBEW, 419 U.S. 428, 431, 438, 448 (1975). See also United States v. Allegheny-Ludlum Steel Corp., 406 U.S. 742, 757 (1972); 1 K. DAvis, Admisistrative LAw Treitise $\$ 1.04$, at 30 n.25 (1958). However, to the extent that recent cases have adopted a "flexible" interpretation of due process, under which the type of procedure required varies with the nature of the controversy and the interests at stake, the rigid adoption of full formal hearing requirements which IVong Yang Sung would require is inevitably called into question. See note 26 infra.

23. The opinions generally cited as first establishing the distinction between types of action are Londoner v. Denver, 210 U.S. 373, 378 (1908) (hearing required for property assessment where assessment based on the effect of public improvements on individual property values), and Bi-Metallic Inv. Co. v. State Bd. of Equalization, 239 U.S. 441, 445-46 (1915) (Holmes, J.) (no hearing required for general increase in valuation of taxable property).

24. Langevin v. Chenango Court, Inc., 447 F.2d 296, 300-01 (2d Cir. 1971). But cf. United States v. Florida E. Coast Ry., 410 U.S. 224, 242-46 (1973); United States v. Allegheny-Ludlum Steel Corp., 406 U.S. 742,757 (1972).

25. See Bell Tel. Co. v. FCC, 503 F.2d 1250, 1266.68 (3d Cir. 1974), cert. denied, 95 S. Ct. 2620 (1975); I K. Davis, Administrative L.aw Treatise $\$ \$ 6.05$, 7.02-.01 (1958); 2 id. \$ 15.03; Robinson, The Making of Administrative Policy: Another Look at Rulemaking and Adjudication and Administrative Procedure Reform, 118 U. PA. L. REV. 485, 503-05, 520-25 (1970); Note, The Judicial Role in Defining Procedural Requirements for Agency Rulemaking, 87 Harv. L. Rev. 782, 786-90 (1974).

26. Interestingly, this has taken place at the same time as a great expansion in the right to such a hearing prior to governmental deprivation of personal entitlements in such things as welfare benefits, parole, or goods bought on credit. See, e.g., North Gcorgia Finishing, Inc. v. Di-Chem, Inc., 419 U.S. 601 (1975) (garnishment of corporation's bank account); Morrissey v. Brewcr, 408 U.S. 471 (1972) (revocation of parole); Goldberg v. Kelly, 397 U.S. 254 (1970) (termination of welfare benefits); Sniaclach v. Family Fin. Corp., 395 U.S. 337 (1969) (garnishment of wages). Even here, however, some of the latest decisions imposing additional procedures require only brief notice and informal hearing and specifically reject any per se rights to summon or cross-examine witnesses or have the assistance of counsel. See Goss v. Lopez, 419 U.S. 565, 582-83 (1975) (suspension of public school students); Wolff v. McDonncll, 418 U.S. 539 (1974) (prison disciplinary procecdings). For a general discussion of the need for flexible hearing requirements, sce Fricndly, "Some Kind of Hearing," 123 U. PA. L. REv. 1267 (1975). 


\section{Formal Records and Informal Rulemaking}

The facts at issue and interests involved have been characterized almost uniformly against such claims. ${ }^{27}$ Indeed, even where the governing statute explicitly prescribes an administrative hearing, courts have increasingly read it to require only a legislative-type proceeding, without a formal presiding officer, a formal record or opportunity for crossexamination. ${ }^{28}$

Finally, even where an adjudicatory hearing concededly is required by statute before a given action may be taken, the courts have sustained the use of summary. judgment procedures, under which the right to an adjudicatory hearing is conditioned on a threshold showing that substantial factual issues will be raised. ${ }^{29}$ The combination of these tendencies, together with the marked congressional trend to rulemaking, has in recent years tipped more and more important agency actions down the scale from formal adjudication to informal rulemaking. ${ }^{30}$

27. In both Anaconda Co. v. Ruckelshaus, 482 F.2d 1301 (10th Cir. 1973), and South Terminal Corp. v. EPA, 504 F.2d 646 (1st Cir. 1974), regulatory actions by EP.A were held to be rulemaking and not to require an adjudicatory hearing even though only one source of pollution, owned by a single company, would be affected. The court in Anaconda pointed to the wide range of interested persons and to the potential for delay. 482 F.2d at 1307. The court in South Terminal added that the purpose of the rule at issue was the "legislative" one of setting policy, not singling out an individual for punishment, and that the facts behind it were not "adjudicative." 504 F.2d at 660-61. See also Note, supra note 25 , at 786 \& $\mathbf{n} .24$.

Claims to a de novo, trial-type hearing before the reviewing court, rather than before the agency, have suffered the same fate. See Camp v. Pitts, 411 U.S. 138, 141 (1973); Citizens to Preserve Overton Park, Inc. v. Volpe, 401 U.S. 402, 415 (1971).

28. See United States v. Florida E. Coast Ry., 410 U.S. 224, 236-37, 241 (1973), and the discussions of that case in Friendly, supra note 26 at 1305-10, and Verkuil, Judicial Review of Informal Rulemaking, 60 VA. L. REv. 185, 195-96 (1974). However, in some cases where such a hearing was desired, the courts, though ruling out claims as of right to a full range of formal procedures, have suggested that limited cross-examination might be required upon an appropriate showing of need. See O'Donnell v. Shaffer, 491 F.2d 59, 62 (D.C. Cir. 1974); American Airlines v. C.\$B, 359 F.2d 624, 632-33 (D.C. Cir.), cert. denied, 385 U.S. 843 (1966).

For a recent study concluding that the right of limited cross-examination so conferred has been little used and has proved of little benefit, see Williams, "Hybrid Rule-Making" Under the Administrative Procedure Acl: A Legal and Empirical Analysis, 42 U. CHr. L. REv. (1975; forthcoming) [citations are to a draft on file with Yale Law Journal] (a report to the Committee on Judicial Review of the Administrative Conference of the United States).

29. See Weinberger v. Hynson, Wescott \&. Dunning, Inc., 412 U.S. 609, 620-22 (1973); United States v. Storer Broadcasting Co., 351 U.S. 192, 205 (1956).

Judge Leventhal has suggested that even where the issues are too unclear to allow an open-and-shut summary judgment procedure to be invoked, the agency, despite the statute, may in some cases legitimately grant a hearing that falls short of what the AP.A specifies for full-scale adjudications. See Cooper Laboratories, Inc. v. Commissioner, FD.l, 501 F.2d 772, 793 (D.C. Cir. 1974) (Leventhal, J., dissenting).

30. However, in addition to their willingness to scale down more formal types of procecdings into notice and comment rulemaking, the federal courts have displayed a new willingness to scale up less formal actions into the same category. Elimination of any notice and comment period is authorized for "interpretative rules, general statements of policy, or rules of agency organization, procedure, ox practice," 5 U.S.C. $\$$ 
This result, some commentators argue, has been accomplished at the expense of respect for precedent and legislative history. ${ }^{31}$ Yet the reasons why the courts strained to reach it are readily understood. During the 1960 's, such administrative horror stories as the peanut butter case:2 highlighted the dangers of undue formality in administrative proceedings. Subsequent scholarship has shown that use of adjudicatory hearings and, in particular, exhaustive probing of individual facts through cross-examination is self-defeating in complicated regulatory programs. ${ }^{33}$

553(b)(A) (Supp. III 1973), and, of course, is not required for those actions which are not "rules" at all. Nonetheless the courts seem to be increasingly willing to impose the notice and comment requirements of $\$ 553$ to actions which are arguably of these types. Sec Pickus v. United States Bd. of Parole, 507 F.2d 1107, 1112-14 (D.C. Cir. 1974); Portland Cement Ass'n v. Ruckelshaus, 486 F.2d 375, 398 n.91 (D.C. Cir. 1973); Hamilton, supra note 9, at 1314 n.175 ("courts have been suspicious of rules promulgated without the opportunity for comment"). See also Wright, supra note 1 , at 375 \& n.l.

31. See Friendly, supra note 26, at 1305-10; Nathanson, Probing the Mind of the Administrator: Hearing I'ariations and Standards of Judicial Review under the Ad. ministrative Procedure Act and Other Federal Statutes, 75 Colvm. L. REv. 721, 768 (1975) ("It must be obvious by now that I regard these [developments], whether already achieved or only anticipated, as distortions of the original meaning of the AP, , especially if the Act is interpreted in accordance with the conventional administrative law wisdom generally accepted at the time of its enactment."); Williams, supra note 28, at 59.62.

32. This mammoth formal hearing involved the question how high a peanut content a mixture of oil and peanuts would have to have before it could be called "peanut butter." See National Nutritional Foods Ass'n v. Weinberger, 512 F.2d 688, 698 n.8 (2d Cir. 1975) ("The notorious proceeding which established standards of identity for peanut butter lasted more than 10 years."); J. Goulden, THE SuperLawyers 185-89 (1971); Hamilton, supra note 9, at 1287-88.

33. According to Professor Hamilton:

The actual agency experience with [formal rulemaking] requirements raises serious doubts about their desirability. At best, some agencies have learned to live with them, even though preferable procedures are probably available. At worst, these procedures have warped regulatory programs or resulted in virtual abandonment of them.... [T] [Te primary impact of these procedural requirements is often not... the testing of agency assumptions by cross-examination, or the testing of agency conclusions by courts on the basis of substantial evidence of record. Rather these procedures either cause the abandonment of the program ..., or the promulgation of noncontroversial regulations by a process of negotiation and compromise....

Hamilton, supra note 9, at 1312. Upon examining the subsequent history of three cases in which the courts had granted a limited right of cross-examination in connection with rulemaking, Professor Williams discovered that

cross-examination was traded away or abandoned by parties in two of the three cases where the courts insisted on its availability,... and in the third... it cannot be said to have played a critical role in building the challengers' record for appeal.

Williams, supra note 28 , at 48 . In view of the apparent lack of utility of cross-examination in actually helping to analyze the merits of a proposed rule, Professor William: suggests some other reasons why a right of cross-examination in rulemaking is so often requested. He points out that such a right, when conferred, creates a potential for delay, grants the regulated parties a bargaining chip and a source of pressurc for more lenient regulation, may chill the willingness of experts to work for the agency and "may score points whose value is more apparent than real," particularly in the cross-examination of experts. Id. at $39-40$. He recommends that any such right of cross-examination be most severely restricted.

Judge Friendly also has been a source of adverse comment on the absolute right of crossexamination. See Friendly, supra note 26, at 1283-85. Judge Friendly described as follows 


\section{B. Judicial Review of Informal Action}

\section{The Availability of Review}

In the absence of another specific statutory provision, jurisdiction to review the actions of federal agencies lies in the federal district courts. ${ }^{34}$ Almost invariably, however, particular regulatory statutes establish circuit courts of appeals as alternative forums for initial review, at least of some actions. ${ }^{35}$ District court review is increasingly held to be unavailable where review at a higher level is provided. ${ }^{36}$

Often an agency's governing statute restricts circuit court review to "orders." "Order," like "rule," is of course a term of art used in the APA to describe the product of a particular process. But the terms "rule" and "order" in a governing statute have not always been read to harmonize with the APA's usage. Hence, in the past, it was frequently unclear whether a given APA rule fit within the definition of an "order" as the latter term was used in the relevant judicial review provision, and thus whether the rule could be reviewed prior to its enforcement. ${ }^{37}$ This reflected the generally confused state of

his experience in reviewing FD.A formal rulemaking which established standards of identity and labeling requirements for vitamins:

The agency hearing transcript comprised more than 32,000 pages and the material sent us, consisting of selected portions of the record, filled three feet of shelf space. The use of trial-type procedures had been of little avail; cross-examination of government witnesses, which filled some $60 \%$ of the pages devoted to the Government's presentation, yielded precious few admissions or other statements of any significance. Ironically, the hearing examiner had denied cross-examination in the one instance where it might have been most useful.

Friendly, supra note 26, at 1306 n.199, discussing National Nutritional Foods Ass'n v. FD.1, 504 F.2d 761 (2d Cir. 1974), cètt. denied, 420 U.S. 946 (1975).

34. Jurisdiction is conferred on these courts either by the general federal question statute, 28 U.S.C. $\$ 1331$ (Supp. III 1973), or in some cases by the Mandamus and Venue Act of 1962,28 U.S.C. $\$ 1361$ (1970). Jurisdiction may also be conferred by the judicial review provisions of the APA, 5 U.S.C. $\$ 702$ (Supp. III 1973), but the courts of appeals are divided on that question. Compare Aguayo v. Richardson, 473 F.2d 1090, 1101-02 (2d Cir. 1973) (Friendly, J.), cert. denied, 414 U.S. 1146 (1974), with Pickus v. United States Bd. of Parole, 507 F.2d 1107, 1109-10 (D.C. Cir. 1974).

35. See Curric \& Goodman, Judicial Review of Federal Administrative Action: Quest for the Optimum Forum, 75 Colum. L. REv. 1, 5 \& nn.12-18, 40 n.154 (1975). Among the agencies whose statutes contain such a provision are the EPA, 33 U.S.C. $\$ 1369$ (Supp. III 1973), 42 U.S.C. $\$ 1857 \mathrm{~h}-5$ (1970); FCC, 28 U.S.C. $\$ 2342(1)$ (1970), 47 U.S.C. $\$ 402$ (Supp. III 1973); FPC, 15 U.S.C. $\$ 717 n(b)$ (1970); FTC, 15 U.S.C. $\$ 45(c)$ (1970); NLRB, 29 U.S.C. $\$ 160(e)$, (f) (1970); NTSB (National Transportation Safety Board), 49 U.S.C. $\$ 1486$ (1970); OSH. (Occupational Health and Safety Administration), 29 U.S.C. $\$$ 655(f) (Supp. III $1973)$.

36. See Vorkuil, supra note 28 , at 200 \& n.68.

37. Compare Columbia Broadcasting Sys. v. United States, 316 U.S. 407 (1942) (review granted), with United Gas Pipe Line Co. v. FPC, 181 F.2d 796 (D.C. Cir.), cert. denied, 340 U.S. 827 (1950) (review denied). The reason given for declining to review the product of informal rulemaking in the latter case was that by limiting judicial review to orders formulated after formal proceedings, Congress had recognized that "an appellate court has no intelligible basis for decision unless a subordinate tribunal has made a record fully encompassing the issues." 181 F.2d at 799 . 
the law on whether a given controversy was clearly enough defined and immediate enough to be ripe for judicial review. ${ }^{3 s}$ Under current interpretations of the words "order" and "ripeness," early judicial review of rules has now become routinely available. In Abbott Lab. oratories $v$. Gardner, ${ }^{39}$ the Supreme Court held that an administrative decision was ripe if it "has been formalized and its effects felt in a concrete way by the challenging parties." 10 "Order" has likewise been redefined in a series of cases to refer less and less exclusively to the product of adjudicatory proceedings. ${ }^{ \pm 1}$ Increasingly, the result has been early judicial review of rules by the courts of appeals, outside the limiting context of a specific enforcement proceeding and without the structuring influence of a prior formal hearing either before the agency or before a district court. ${ }^{42}$

\section{The Standard of Review}

The Administrative Procedure Act provides three tests which potentially might be used to review findings of fact made in the course

38. For a description of the law as it was a few years ago, see $3 \mathrm{~K}$. D.Avis, AduinistruTIVE LAW TREATISE $\$ \S 21.01-21.10$ (1958).

39. 387 U.S. 136 (1967).

40. Id. at 148-49. The context makes clear that reasonably anticipated future effects are "felt in a concrete way." Professor Davis has supplemented his treatise with a discussion of the recent clarification of "ripeness" law. See K. Davis, Administrative Law TrEATISE \$ 21.00 (Supp. 1970).

41. See, e.g., Phillips Petroleum Co. v. FPC, 227 F.2d 470 (10th Cir. 1955), cert. denied, 350 U.S. 1005 (1956) (rate filing suspension held to be "order" despite lack of hearing, record or findings); Verkuil, supra note 28 , at 196-205. In a recent case on the interpretation of "order," Pacific Gas \& Elec. Co. v. FPC, 506 F.2d 33, 47-48 (D.C. Cir. 1974), the court said that "in recent years the courts have been more inclined to accept jurisdiction over rules as well as administrative orders" and added that the trend of the cases was to "eliminate the arbitrary distinction ... between adjudicative orders and other agency pronouncements" as far as reviewability was concerned in favor of "a more practical analysis, concentrating on whether the issues and the record were suitable for judicial review and whether the agency's order had an immediate and significant impact on petitioners."

42. This development, too, has been said to go against legislative history:

Section 553's notice-and-comment provisions were [originally] conceived of as instruments for the education of the administrator, especially on questions of policy; there is not the slightest indication that the purpose of the notice-and-comment proceeding was to develop a record by which a reviewing court could test the validity of the rule which the Administrator finally adopted.

Apparently, an underlying assumption of the APA draftsmen was that any factual issues which became pertinent in a challenge to the validity of a section 553 rule would be resolved in the first instance in judicial proceedings-either in enforcement proceedings or in suits to enjoin enforcement. It must also have been assumed that such proceedings would take place in the first instance in a federal district court-a court accustomed to resolving such factual questions even if it might, in some instances, be a three-judge court.

Nathanson, supra note 31 , at 754-55 (footnotes omitted). 
of rulemaking. Such findings and conclusions, the statute provides, may be set aside when found to be

(A) arbitrary, capricious, an abuse of discretion, or otherwise not in accordance with law; ...

(E) unsupported by substantial evidence in a case subject to [ 5 U.S.C. \$\$] 556 and $557 \ldots$ or otherwise reviewed on the record of an agency hearing provided by statute; or

(F) unwarranted by the facts to the extent that the facts are subject to trial de novo by the reviewing court. ${ }^{43}$

As a practical matter, the question of which test should be applied in judicial review of informal rulemaking was settled by the Supreme Court in Citizens to Preserve Overton Park, Inc. v. Volpe, even though that case did not actually involve informal rulemaking. In reviewing the decision of the Secretary of Transportation to allow a highway to be built through a public park, ${ }^{+5}$ the Court rejected both substantial evidence and trial de novo review in favor of a determination whether the decision at issue could be said to be arbitrary or capricious." ${ }^{45}$ The Court cautioned, however, that despite

43. The remainder of the APA section specifying the standard of judicial review of agency action reads as follows:

To the extent necessary to decision and when presented, the reviewing court shall decide all relevant questions of law, interpret constitutional and statutory provisions, and determine the meaning or applicability of the terms of an agency action. The reviewing court shall-

(1) compel agency action unlawfully witheld or unreasonably delayed; and

(2) hold unlawful and set aside agency action, findings, and conclusions found to be-

…

(B) contrary to constitutional right, power, privilege, or immunity;

(C) in excess of statutory jurisdiction, authority, or limitations, or short of statutory right;

(D) without observance of procedure required by law;

....

In making the foregoing determinations, the court shall review the whole record or those parts of it cited by a party, and due account shall be taken of the rule of prejudicial crror.

5 U.S.C. $\$ 706$ (Supp. III 1973). Tests (B), (C) and (D) are confined to straightforward matters of law, and within their limits prestmably apply equally to review of rulemaking and of administrative adjudication.

44. 401 U.S. 402 (1971).

45. The Secretary's decision is an example of administrative action which is less formal than informal rulemaking. See note 14 supra.

46. The substantial evidence test, the Court said, was not applicable because the hearing required by the statute before approval for construction of the highway could be given was

nonadjudicatory, quasi-legislative in nature. It is not designed to produce a record that is to be the basis of agency action-the basic requirement for substantialevidence review.

401 U.S. at 415. But see Note, Judicial Review of the Facts in Informal Rulemaking: $A$ Proposed Standard, 84 YALE L.J. 1750, 1752, 1756 (1975) (arguing that the language of 
the adoption of what seemed to be the least stringent of the three APA tests, the reviewing court would have to undertake a "searching and careful" inquiry into the facts, and would also have to consider "whether the decision [under review] was based on a consideration of the relevant factors and whether there has been a clear error of judgment." 47

The circuit courts have almost universally reacted to Overton Park by adopting the arbitrary or capricious test for review of informal rulemaking. ${ }^{48}$ The invitation to make a searching and careful inquiry into the facts also has been enthusiastically accepted. The result has been

the APA requires substantial evidence review of factual determinations in informal rulemaking, despite its nonadjudicatory, quasi-legislative nature). As for trial de novo, the Court said that it is

authorized ... in only two circumstances. First, such de novo review is authorized when the action is adjudicatory in nature and the agency factfinding procedures are inadequate. And, there may be independent judicial factfinding when issues that were not before the agency are raised in a proceeding to enforce nonadjudicatory agency action. ... Neither situation exists here.

401 U.S. at 415 (citations omitted).

47. 401 U.S. at 416. The Court did caution, however, that the district court "is not empowered to substitute its judgment for that of the agency." Id.

48. See South Terminal Corp. v. EPA, 504 F.2d 646, 655 (1st Cir. 1974); Buckeye Power, Inc. v. EPA, 481 F.2d 162, 171 (6th Cir. 1973); Delaware Citizens for Clean Air, Inc. v. Administrator U.S. EPA, $480 \mathrm{F.2d} \mathrm{972,} \mathrm{975-96} \mathrm{(3d} \mathrm{Cir.} \mathrm{1973)} \mathrm{(the} \mathrm{substantial}$ evidence test is not applicable because no decision on the record of a hearing is required); Appalachian Power Co. v. EPA, 477 F.2d 495, 505 (4th Cir. 1973). Contra, Texas v. EPA, 499 F.2d 289, 296-97 \& n.7 (5th Cir. 1974). In Texas, the court was betrayed by Overton Park into making the unfortunate statement that if EP.A's action had been rulemaking, the applicable standard of review would be substantial evidence rather than arbitrary or capricious. EPA's action was in fact rulemaking.

The shift away from the substantial evidence standard has occurred even though the Court in Overton Park stated explicitly that "[r]eview under the substantial-cvidence test is authorized only when the agency action is taken pursuant to a rulemaking provision of the Administrative Procedure Act itself, 5 U.S.C. $\$ 553$. . . 401 U.S. at 414. This statement does not square with the view expressed a page later in the opinion that the substantial evidence test only applies where a hearing is held that is "designed to produce a record that is to be the basis of agency action." See note 46 supra. In rulemaking under $\$ 553$ there is no statutory requirement for either record or hearing. See Verkuil, supra note 28, at 212 (first Overton Park statement is "unfortunate dictum"). In practice, however, the circuit courts have completely ignored the first statement, in. stead adopting the arbitrary or capricious test to review of agency rulemaking.

On the other hand, the Supreme Court has apparently applied the substantial evidence test to judicial review of informal rulemaking in several cases after Overton Park, though without discussing the point. See United States v. Allegheny-Ludlum Steel Corp., 406 U.S. 742 (1972); United States v. Midwest Video Corp., 406 U.S. 649, 67I (1972); Note, supra note 46 , at $1756-58$.

Whatever the label used, this new approach marks a significant change from the one taken when rules were less important forms of agency action than they are now, and judicial review of them was less freely available. In those days rules rarely dealt with complicated factual subjects, and the conventional wisdom was that due to thcir "legislative" nature they were little more subject to factual review than statutes. See, e.g., Pacific States Box \& Basket Co. v. White, 296 U.S. I76, 186 (1935) (Brandeis, J.); Verkuil, supra note 28, at 206-07. The reasons for the change are well expressed in Chicago v. FPC, 458 F.2d 731, 741-43 (D.C. Cir. 1971), cert. denied, 405 U.S. 1074 (1972). 
to transform the arbitrary or capricious test into something very close to substantial evidence review. ${ }^{\text {} 9}$

Such a development was probably inevitable given the complexity of the problems now being addressed by rulemaking. Distinctions between degrees of inquiry tend to evaporate in the face of highly technical and novel factual issues and the complex web of intellectual and policy choices in which they are often embedded, a web which may make two or three or many different approaches intellectually defensible. ${ }^{50}$ Any standard of review of the substantive merits of an action requires a court to understand those merits, and when a new and complex rule is being considered, the mere effort which must be exerted to do that will translate itself almost automatically into a fairly rigorous probing and exposure of what the agency has done.

However, this more rigorous judicial scrutiny has been accompanied in some areas by a relaxation of the factual showing the agency ultimately must make before its rules will be sustained. The tremendous uncertainties that may surround the consequences of actions in the spheres in which the Environmental Protection Agency and some other agencies operate have led the courts to moderate any requirement that regulations be supported by "proof" in some hard and factual sense. Rather than show that harm will occur if a given action is not taken, the agency simply is required to show that a risk of harm

49. See Note, supra note 46, at 1753-56. Several judges have noted the tendency of these two tests to converge. See National Nutritional Foods Ass'n v. Weinberger, 512 F.2d 688, 705 (2d Cir. 1975) (Lumbard, J., concurring) ("In essence I think that when an agency engages in substantive rule-making, it abuses its discretion (or acts arbitrarily or capriciously) if its actions are not supported by substantial evidence."); Synthetic Organic Chem. Mfrs. Ass'n v. Brennan, 503 F.2d 1155, 1158 (3d Cir. 1974); Associated Indus, v. United States Dep't of Labor, 487 F.2d 342, 349.50 (2d Cir. 1973) (Friendly, J.); Bunny Bear, Inc. v. Peterson, 473 F.2d 1002, $1005-06$ (1st Cir. 1973); Leventhal, Environmental Decisionmaking and the Role of the Courts, 122 U. PA. L. REv. 509, 540-41 (1974).

Cases under the judicial review provisions of the Occupational Safety and Health Act, 29 U.S.C. $\$ 655(f)(1970)$, which provide that rules will be affirmed if they meet a substantial evidence test even though the rulemaking proceedings are informal, have been cited and relied on by courts as they reviewed other rules and simultancously applied the arbitrary or capricious standard. Thus, Industrial Union Dep't v. Hodgson, 499 F.2d 467, 474-75 (D.C. Cir. 1974), an OSH.A case, was cited and relied on in Amoco Oil Co. v. EP.A, 501 F.2d $722,739-41$ (D.C. Cir. 1974), and relied on indirectly in South Terminal Corp. v. EPA, 504 F.2d 646, 655 n.6 (1st Cir. 1974), cases arising under the Clean Air Act, 42 U.S.C. $\$ \$ 1857-5$ il (Supp. III 1973).

For another illustration of this convergence, compare Chrysler Corp. v. Department of Transp., 472 F.2d 659, 667.68 (6th Cir. 1972) (substantial evidence), with Boating Indus. Ass'n v. Boyd, 409 F.2d 408, 411 (7th Gir. 1969) (arbitrary or capricious), and Automotive Parts \& Accessories Ass'n v. Boyd, 407 F.2d 330 (D.C. Cir. 1968) (same).

50. See Boyer, Alternatives to Administrative Trial-Type Hearings for Resolving Complex Scientific, Economic, and Social Issues, 71 MIcr. L. REv. 111, 116-20 (1972). See generally Wright, supra note 1 , at 388-89. 
will be generated, and that this risk is substantial enough to justify a given regulatory response. ${ }^{51}$

This development has been recognized. ${ }^{52}$ But a corollary has not. Whatever the nominal standard of review applied, courts have been on notice, since the decisions of the Supreme Court in Morgan $v$. United States, ${ }^{, 33}$ not to "probe the [actual] mental processes" 54 of the decisionmaker by cross-examination or disclosure of briefing materials. Instead, they are limited to an inquiry whether the decision makes sense in terms of the applicable legal criteria, the material formally considered in making it, and the reasons formally given. The only significant exception to that rule arises where a "strong [preliminary] showing of bad faith or improper behavior" has been made..$^{55}$ Then, "the courts will inquire into the administrative process in order to insure that the decision making was informed, unbiased, and [to the extent required by law] personal." ${ }^{\circ}$

The greatly increased scope of the subjects addressed by rulemaking and the development of a more flexible burden of proof do not affect the Morgan bar directly. But to the extent that they expand the authority of the agency and carry with them a potential for abuse, they increase pressures either for more formal procedures or for fuller inquiry into the actual workings of the administrative process itself.

\section{The Neglect of Procedure}

The developments outlined above contain a paradox. Judicial review of rules is far more frequent and searching than in the past. Yet the formal administrative hearings which used to precede such review have largely been abandoned. Preenforcement review by the courts has preempted both adjudicatory proceedings at the agency level and judicial review through trial de novo as the forum for challenging the promulgation of rules. Courts and commentators unhappy with this development have suggested reinstituting formal hear-

51. Reserve Mining Co. v. EPA, 514 F.2d 492, 507 (8th Cir. 1975); Industrial Union Dep't v. Hodgson, 499 F.2d 467, 474-76 (D.C. Cir. 1974). See Texas v. EP.A, 499 F.2d 289, 301 \& n.16 (5th Cir. 1974) (recognition that EPA's obligation to take action within a statutory deadline might necessarily lead to reliance on imperfect data); Applications for Suspension of 1977 Automobile Exhaust Emission Standards; Decision of the Administrator, 40 Fed. Reg. 11900 (1975).

52. See, e.g., Gelpe \& Tarlock, The Uses of Scientific Information in Environmental Decisionmaking, 48 S. CAL. L. REv. 371 (1974); Note, supra note 46, at 1761-66.

53. Morgan v. United States, 313 U.S. 409 (1941) (Frankfurter, J.) (Morgan IV'); Morgan v. United States, 304 U.S. I (1938) (Morgan II).

54. 304 U.S. at 18.

55. Citizens to Preserve Overton Park, Inc. v. Volpe, 401 U.S. 402,420 (1971).

56. KFC Nat'l Management Corp. v. NLRB, 497 F.2d 298, 305 (2d Cir. 1974). 
ings. ${ }^{57}$ Yet, as most of these same authorities recognize, this is a nostalgic and unrealistic hope.

This retrospective focus on the full machinery of adjudication does not recognize that a formal proceeding is made up of many different procedures, of which a trial-type hearing is only the most prominent. The failure to make this distinction meant that as cross-examination and the whole courtroom machinery of motions, pleadings, and presiding officer were abandoned, the other procedures that historically have gone along with them were dispensed with too. Most important of these abandoned trappings was the requirement that a final agency decision be explained in terms of a record to which all parties had an opportunity to contribute. In consequence, as the following description of rulemaking at the Environmental Protection Agency will demonstrate, the procedures used in informal rulemaking have become too informal, impairing both the development of rules within the agency and their subsequent review by the courts.

\section{Informal Rulemaking at EPA}

The Administrative Procedure Act is only a statute; it is not the source of all agency procedures. Commentators who focus too narrowly on the APA may forget what lies behind it, and the long paths an agency rule may have to trace before even being proposed for comment. Those who hope to improve agency rulemaking should first understand how agencies work internally.

The following description of rulemaking at the Environmental Protection Agency ${ }^{\text {ss }}$ provides some of that background. Though EPA is

57. Courts in OSHA cases have expressed dissatisfaction at having to apply a substantial evidence test in the absence of an adjudicatory hearing. See Synthetic Organic Chem. Mfrs. Ass'n v. Brennan, 503 F.2d 1155, 1158 (3d Cir. 1974); Industrial Union Dep't v. Hodgson, 499 F.2d 467, 469, 473, 474, 476 (D.C. Cir. 1974). Indeed, the need for such a hearing has been suggested where courts review facts in detail under the arbitrary or capricious test. See Texas v. EP.A, 499 F.2d 289, 321 (5th Cir. 1974) (concurring opinion).

To date, however, only one court has held that even the words "substantial evidence" in a statute necessarily imply formal hearing procedures, and even it stopped short of saying the full range of courtroom procedures was necessary. See Mobil Oil Corp. v. FPC, 483 F.2d 1238, 1258-60, 1262-63 (D.C. Cir. 1973). Judge Bazelon has taken the dissatisfaction expressed in these cases one step further, arguing that courts are simply incapable of dealing with the kind of vastly complicated factual isstes that now come before them. From this he concludes that they should restrict themselves instead to oversecing the procedures by which agencies make decisions, and that formal hearing procedures should be largely reinstituted to give them some procedures to oversee. See Friends of the Earth v. AEC, 485 F.2d 1031, 1032-33 (D.C. Cir. 1973) (two-judge panel) (separate statement of Bazelon, J.); International Harvester Co. v. Ruckelshaus, 478 F.2d $615,650-53$ (D.C. Cir. 1973) (concurring in result). But see Friends of the Earth v. AEC, supra at 1035 (separate statement of Leventhal, J.).

58. The Environmental Protection Agency was created in 1970 , not by legislation, but by executive action subject to congressional veto. See note 3 supra. It consisted originally of pollution control programs taken from various other federal agencies. Indeed, the 
only one of many rulemaking agencies, it has been extraordinarily active in the past few years. ${ }^{59}$ Judicial opinions reviewing its regulations often have pointed out problems and marked new directions in the field of administrative law generally. Despite the following discussion, I believe EPA is one of the best regulatory agencies so far as staff competence and morale, quality of top leadership, and political courage are concerned. Though it certainly has extensive patches of laziness and ineptitude, in many cases good staff work compensates for the procedural deficiencies described below.

To a large extent, confusion and uncertainty are endemic to the bureaucratic process, particularly in a new agency. With new statutes to implement, with subject matter that is technically uncertain and highly controversial, with so many people involved, so many competing interests, and so many diverse views, there is no way to tie up all the loose ends. Though this article does suggest specific reforms, they will at most alleviate the problems. ${ }^{60}$

\section{A. Internal Procedures: Lead Offices, Working Groups, Steering Committees and $O M B$}

By internal agency and executive branch directives, ${ }^{81}$ EPA and the

purpose of its creation was to put all major federal pollution control programs under one roof.

At present, EPA is a medium-sized bureaucracy with about 9,000 full-time employces in five major divisions: air pollution, noise, and solid waste; water pollution and pesticides programs; research and development; planning, program evałuation and agency management; and enforcement. Several smaller activities, such as congressional relations, international affairs, and recently the General Counsel's office are independent of these divisions and report to the Administrator directly. See Organization of the Environmental Protection Agency, EPA Order No. 1110.18D (June 5, 1975) (on file with Yale Law Journal); Transfer of the Office of General Counsel to the Office of the Administrator, EPA Order No. 1120.9 (Jan. 17, 1975) (on file with Yale Law Journal).

59. To pick one imperfect measure, the EPA has roughly doubled the volume of its regulations annually. The first compilation of EPA regulations, which covered all regulations issued before January 1, 1972, was 460 pages long. 40 C.F.R. (1972). The second compilation, which added the 18 months from January, 1972, to the beginning of July, 1973 , was 1012 pages long. 40 C.F.R. (1973). Since then the compilations have been updated annually. The 1974 edition contained 1907 pages, 40 C.F.R. (1974), and the 1975 edition, now in press, will be much longer.

60. I do not mean to suggest that bureaucracy is a particularly incompetent form of human endeavor. Though I have never worked there, I feel reasonably certain that similar observations could be made about decisionmaking in the Congress or the White House, or in a university faculty or large corporation. I have worked in a large law firm, and it was my experience that even these institutions have unquestioned attitudes and practices, folkways and taboos, that often prevent them from reacting to problems in the most rational or effective way.

61. Policy and Procedures for the Standards and Regulations Development Process, EPA Order No. 1000.6 (Dec. 10, 1971) (on file with Yale Law Journal); Agency Regulations, Standards and Guidelines Pertaining to Environmental Quality, Consumer Protection, and Occupational and Public Health and Safety, Memorandum to Heads of Departments and Agencies from George P. Schultz, Director, Office of Management and Budget (Oct. 5, 1971) (on file with Yale Law Journal). 
Office of Management and Budget $(\mathrm{OMB})^{62}$ command a far more elaborate approach to rulemaking than anything that the Administrative Procedure Act standing alone requires. ${ }^{63}$

Under internal EPA directives, the first formal step in drafting a regulation is to assemble an ad hoc "working group" composed of EPA staff members who have particular interest or competence in a field. ${ }^{b 4}$ Needless to say, not all members of the working group participate actively; often most of the work is done by a few members. The most active are usually those representing the "lead office" or "office of primary interest"-the office which first had the idea for the rule or has been assigned responsibility for it. This office typically will far outdistance others in familiarity with the technical issues involved. Indeed, the evidence of that familiarity, when written down at all, may be very difficult for those outside the lead office to examine, since it is often scattered through various studies, correspondence, and contractors' reports ${ }^{65}$ in the possession of the lead office. More data, of course, may be similarly scattered through other offices. There is no formal mechanism to specify what the working groups should

62. The Office of Management and Budget was created out of the old Bureau of the Budget by Reorganization Plan No. 2 of 1970, 35 Fed. Reg. 7959, 84 Stat. 2085, which became effective on July 1, 1970, pursuant to 5 U.S.C. $\$ 906$ (1970). It is part of the Executive Office of the President. In addition to overseeing the development of each agency's budget each year, it is supposed to improve government organization, information, and management systems and to help the President run the executive branch as a unified whole.

63. These rulemaking requirements only begin to apply, of course, once some element of the agency has decided it would like to see a rule developed and promulgated. At E.P.1 at least, however, the decision to make that effort has literally been compelled in most instances. The governing statutes require rules on a wide variety of subjects to be promulgated within tight deadlines.

Euvironmental groups have been most successful in lawsuits designed to force compliance where those deadlines have been missed. See, e.g., Natural Resources Defense Council, Inc. v. EP.A, 475 F.2d 968 (D.C. Cir. 1973) (compelling promulgation of transportation control plans under the Clean Air Act); Natural Resources Defense Council, Inc. v. EP.A, 6 BNA Environ. Rep. Cas. 1033 (D.D.C. 1973), aff'd sub nom. Natural Resources Defense Council, Inc. v. Train, 510 F.2d 692 (D.C. Cir. 1974) (compelling publication of effluent guidelines under the Federal Water Pollution Control Act); Sicrra Club v. Ruckelshaus, 344 F. Supp. 253 (D.D.C.), aff'd without opinion, 4 BNA Environ. Rep. Cas. 1815 (D.C. Cir. 1972), aff'd sub nom. Fri v. Sierra Club, 412 U.S. 541 (1973) (equally divided Court) (compelling the insertion of nondeterioration provisions in state implementation plans under the Clean $\mathrm{Sir} A \mathrm{ct}$ ).

61. Working groups are often put together informally from people who have worked on similar problems in the past. If this is not done, the "office of primary interest" can request the unit of EP. in charge of working groups to form one for it. This office will then contact all portions of the agency that might have an interest in the upcoming regulation and ask them to assign members. In either case, however, each regulation must have an officially recognized working group assigned to it. If it does not, it is not supposed to proceed to the later stages of the review process.

65. Private consulting firms often work on the development of regulations. When this happens, some member of the office of primary interest will be in charge of supervising the contract. 
consider, or even to make sure that all members have a chance to consider the same information. ${ }^{66}$ Disputes are raised and resolved in a catch-as-catch-can way until all the apparent issues have been thrashed out.

The working group then prepares a set of documents for review within EPA. Typically these consist of (1) the draft regulation, complete with explanatory preamble; (2) a technical support document cited in the preamble which contains background information too voluminous to be reprinted in the Federal Register; ${ }^{\text {i7 }}$ and (3) an "action memorandum" addressed to the EPA Administrator to highlight the major uncertainties, policy issues and probable objections to the regulations. Where required, an environmental impact statement $^{68}$ and an inflation impact statement ${ }^{69}$ also will be included. After these materials are assembled, the regulation is ready to move on to the next stage.

This second stage consists of review by the "steering committee."70" The steering committee is composed of permanent representatives from each of the major sections ${ }^{71}$ of EPA plus a few permanent committee staff members. Others may.also attend, ${ }^{72}$ and in practice the steering

66. A recent EPA manual states that guidelines on "maintaining a central project file" for each project handled at the working group level "will be issued shortly." EP.A, Office of Planning and Management, Procedures for the Standards and Regulations Development Process, Dec. 6, 1974, at 6-7 (on file with Yale Law Journal). Such instructions, when they appear, should help alleviate the problem.

67. The technical support document is prepared by the office of primary interest and is designed both to outline the state of the art in the relevant field and to put forward the test data and technical reasoning that support the regulations.

68. This is required by the National Environmental Policy Act of 1969 (NEPA) for "every recommendation or report on proposals for legislation and other major Federal actions significantly affecting the quality of the human environment." 42 U.S.C. $\$ 4332$ (Supp. III 1973). Both the Clean Air Act, 42 U.S.C. $\$ 1857-57 l$ (Supp. III 1973), and the Federal Water Pollution Control Act, 33 U.S.C. $\$ 1251-1376$ (Supp. III 1973), contain explicit legislative exemptions from the impact statement requirement of NEPA for almost all actions taken under their authority. See 33 U.S.C. \$ 1371(c)(1) (Supp. III 1973) (the FWPCA); Energy Supply and Environmental Coordination Act of 1974, 15 U.S.C.A. \$ 793(c)(1) (Supp. 1975) (creating the exemption for Clean Air Act actions). However, EPA has agreed as a matter of policy to write NEPA statements on certain categories of its exempt activities. Sce 39 Fed. Reg. 16186 (1974).

69. This is required by Exec. Order No. 11821, 3A C.F.R. 203 (1975), for "major legislative proposals, regulations, and rules emanating from the exccutive branch which may have a significant impact on inflation."

70. The "steering committee" falls under the jurisdiction of a subunit of EP.I called the Office of Planning and Evaluation, which is headed by a Deputy Assistant Administrator. Most federal agencies have an office of this type, with the function of analyzing agency programs for economic and managerial rationality and consistency with othcr agency programs. They are also supposed to act as devil's advocates to make sure all likely objections have been considered in advance. How well they work is another matter.

71. See note 58 supra.

72. EPA has 19 Deputy Assistant Administrators who rank just below and (with one exception) report to the heads of the five major divisions of the agency. These officials, to oversimplify, serve as the link between the top of the agency, which is basically con- 
committee's weekly meetings generally have a minimum of 15 people in attendance. Steering committee review of draft regulations is limited to consideration of the documents assembled by the working group. Passage through the steering committee is meant to ensure that no significant part of EPA is denied the opportunity to comment from its own perspective when new regulations are developed, and that all new regulations become the subject of disinterested analysis by the permanent staff of the steering committee.

After the steering committee has approved a proposed regulation, but before it is sent to the Administrator for signature, copies of the regulation and the various supporting documents are supplied to the Office of Management and Budget and to other interested agencies and departments for analysis and comment. ${ }^{73}$ Some of these recipients release their copies to industries that would be affected by the proposed regulation and thereafter serve as conduits for industry views. Problems that arise during this review are bargained out between the agencies concerned, with OMB playing a role halfway between that of a judge and that of a moderator. EPA has occasionally been able to get its way even on highly controversial points in this forum. Only after the regulations have cleared OMB are they signed by the Administrator and put out for the public comment contemplated by the APA. After comments have been received, the working group analyzes them and, when necessary, revises the regulations, technical support document, or action memorandum. The revised regulations are then reviewed once again by the steering committee and OMB before promulgation in final form.

\section{B. The Process As It Actually Works}

Simply to outline the formal procedures established for developing and reviewing rules inside the executive branch may give an exaggerated idea of their importance. They do indeed provide a structure

cerned with policy and with representing EPA to the world outside, and the lower levels at which the more detailed technical work is done. Originally it was expected that they would attend the stecring committee mectings; in practice they generally stay away and send one or more representatives. Members of working groups which have items on the agenda often also attend.

73. See Davies \& Lettow, The Impact of Federal Institutional Arrangements, in FEDERAL Environmentat Liw 126, 136-37 (E. Dolgin \& T. Guilbert eds. 1974). Only regulations "pertaining to environmental quality, consumer protection, and occupational and public health and safety" are subject to this process. OMB Memorandum, supra note 6I. This review process catuses far longer delays in rulemaking than anything the Administrative Procedure Act standing alone requires. It is now called "Interagency Review." The title was "Quality of Life Review" until some OMB staff member, conscious of the Orwellian overtones, substituted the present name. 
through which most ${ }^{74}$ agency actions must pass, but other factors tend to diminish their influence.

In most cases, the office of primary interest will care far more about a given rule than any other group. ${ }^{75}$ The work done by the lead office in developing and substantiating a rule may be so thorough that further agency review is almost unnecessary. Whether or not this is the case, however, the dominance of the lead office makes the role of the working group far less significant than a description of the system of review might suggest. As a senior EPA official with long. experience in government said in comments on an earlier draft of this article: ${ }^{\pi 6}$

[R]ulemaking follows the parochial outlook on the Agency's work that is inevitable in so diverse an organization. A rule (an idea for a rule) is generated by that sub-organization that needs the rule to implement what it perceives to be its program. That suborganization does the basic staff work, writes issue and position papers, and drafts a [Notice of Proposed Rulemaking] and briefing memo. . . . WG's [working groups] get into the act rather late in the process-and become active as a forum for sticky issues only if it is not possible to give a nihil obstat imprimatur. ${ }^{77}$

....

... Working Groups really do very little except carp, and protect what they perceive to be their interests. Those of course are important functions, but they are not functions that generate the data on the basis of which a rule is finally issued.

Working groups are supposed to be forums for resolving differences of opinion within the agency before the agency position is fixed in

74. Some of the most important agency actions escape both internal EPA review and OMB review. These have included the various suspensions of auto emission standards, the decision to start proceedings to summarily prohibit the use of the pesticide aldrin/ dieldrin, and the promulgation of transportation control plans to reduce traffic in urban areas. Here a combination of time pressure and the complexity of the subject matter has swamped the usual intra-agency procedures. OMB review has been cut out both for this reason and, in the first two cases, because the statute was very clear that the Administrator of EPA was to make the decision and specified at least a fairly formal procedure for him to use.

In such cases, the Administrator or his top aides have typically worked directly with the staff members most directly concerned. On balance, I believe the decisions made in this manner have been at least as good as those that have gotten the full stecring committee/OMB treatment, though of course the Administrator can only become involved in a handful of decisions.

75. Where large or controversial decisions are concerned, this is less likely to be true, since members of other offices then have a real incentive to become familiar with the problems.

76. Memorandum to William F. Pedersen, Jr. from a senior EPA official, May 4, 1975 (on file with Yale Law Journal) (emphasis in original; name withheld at the official's request).

77. "Let nothing stand in the way of its printing." 
a proposed rule. But to the extent that serious disagreement actually arises, working groups almost automatically cease to contribute to its resolution:

If there is a very sticky issue, it is unlikely to be resolved at the WG level. By the nature of the way EPA is (dis)organized, really sticky issues are escalated at least to the [Deputy Assistant Administrator] level and maybe higher for resolution. [Deputy Assistant Administrators] do not serve on WG's-there's no need for their participation unless irreconcilable differences emerge, and they don't find it useful to attempt to resolve such differences on other than a collegial level. Thus WG's do not really function as intended-they are a forum for formal coordination, but not for creative analysis. ${ }^{7 s}$

The steering committee typically makes even less of a contribution to proposed rules than do the working groups. The same EPA official observed:

[The steering committee] should . . . be a forum for surfacing again reservations about the wisdom of a course of action proposed by another OPI [office of primary interest], but it rarely turns out to be that. The reason, I perceive, is that if the course deemed unwise is not directly harmful to the interest of the office that feels that way that office is reluctant to surface the issue for fear of alienating the OPI-which presumably could throw up a similar issue next time the concerned office had a proposed reg before the SC [steering committee]. Thus objections are raised in SC only when what are perceived as vital interests are at stake.

From my (admittedly infrequent) participation in SC (I have a right to go and speak, but have no time for it and it has little relevance to the real world as I see it) I have noted that little intelligent discussion goes on except among people representing organizations that have a direct interest-which should of course have been settled at the WG level..$^{79}$

The political facts of life often act to preempt both the working group and the steering committee. A main job of higher EPA officials, above the steering committee level, is to remain in contact with outside groups such as industry, environmentalists, Congress and state and local officials and, of course, with their own staffs. When a vital issue arises, in the nature of things it will be swiftly brought to the attention of these officials. A round of informal discussions is likely to ensue, which often takes the main burden of resolving complex or controversial issues.

78. Memorandum, supra note 76 .

79. Id. 
Another set of problems arises because the controversial issues at EPA also tend to be very technical and complex. This has always been true to some extent for the administrative agencies; Congress makes general policy and leaves the nuts and bolts to them. But the increasing complexity of technical knowledge and the growing scope of government regulation have broadened the gap between policy and its implementation and increased the importance of the latter. To take one example, the question whether power plants should be required to install scrubbers to remove sulfur compounds from their stack gasses turns in the first instance on whether the scrubbers will work. But if a given scrubber doesn't work, that may well stem from a lack of proper maintenance, from the omission of some easy adjustment, or from routine development problems that will quite predictably be cleared up as the technology advances. The fact that a scrubber has worked may be due to the nature of the particular fuel or facility, so that no lesson has been learned about the efficacy of the technology generally. When such uncertainties arise, as they do early in the discussion of any even moderately controversial issue, there is really no way to answer them short of a thoroughgoing immersion in the data. ${ }^{\mathrm{N}}$ Yet high government officials, at EPA and certainly still more at OMB (and, I am sure, in other agencies), do not want to be bothered with the details of technical matters if they can possibly avoid it. ${ }^{\text {1 }}$

What is more, the briefing package to which the discussion of a proposed rule is reduced at the steering committee stage is often unable to convey an adequate notion of the complex, uncertain and ambiguous nature of the information and the choices involved. Even when officials realize this and the matter is important, they are often far too busy to master the data. The attitude of these officials toward the regulation in question is thus significantly influenced by which staff members are trusted, which present their case more plausibly, who won last time, and other considerations extraneous to the technical complexities of the regulation itself.

80. This difficulty is reinforced by the intent of both the Clean $\mathrm{Air}$ Act and the Federal Water Pollution Control Act that EP.A set standards not just on the basis of what technology can presently achieve, but on the basis of what it could achieve. with development, in future years. See CPC Int'l, Inc. v. Train, 515 F.2d 1032, 1047-49 (8th Cir. 1975); Portland Cement Ass'n v. Ruckelshaus, 486 F.2d 375, 391 (D.C. Cir. 1973); International Harvester Co. v. Ruckelshaus, 478 F.2d 615, 628-29 (D.C. Cir. 1973); Boninc, The Evolution of Technology Forcing in the Clean Air Act, BNA ENvirow. REP. Monograph No. 21 (1975); Zener, The Federal Law of I'ater Pollution Control, in Frofrux. Environmental Law 682, 705-06 (E. Dolgin \& T. Guilbert eds. 1974).

81. One White House aide is quoted as having said that the scrubber issue "is not the kind of thing we should take a position on because we just don't have the technical expertise." Noone, Great Scrubber Debate Pits EPA Against Electric Ulilities, 6 Natronal JOURNAL REPORTS 1103, 1110 (1974). 
The bureaucratic weight and inertia and the relatively coarse mesh of the review process have two adverse (and seemingly contrary) effects on those who develop regulations. First, stiff or problematical regulations may simply not be pushed because too much bureaucratic counterpressure will be generated. (The impulse for strict regulations must be present at the working group level if there is to be any hope that strict regulations will be issued-the upper levels of review by nature tend to water down regulations in the light of other factors.) Second, regulations that do get pushed may still be arbitrary to some degree, particularly in the direction from which opposition is unlikely. The upper levels of review cannot be thorough enough to catch the technical errors or errors of detail on which the legality and, indeed, the wisdom of the regulations may depend.

\section{The Need for Rigorous Judicial Review}

In these circumstances, detailed factual review of regulations by those with the power to change them takes place in two forums only -at the level of the office of primary interest and working group inside EPA, and in court. The working group generally will understand the technical complexities of a regulation. So to a great extent $t^{82}$ will members of the industry being regulated. But the review process within the agency and the executive branch does not spur a working group to make sure that the final regulation adequately reflects these complexities. ${ }^{83}$ To the extent that internal review is the only review worried about, comments by the affected industry or (to pick a less frequent case) by environmental groups may not be given the kind of detailed consideration they deserve. Since the higher levels of review are unwilling or unable to consider the more complex issues, the best hope for detailed, effective review of complex regulations is the judiciary.

Judge Leventhal's opinions in International Harvester Co. v. Ruckelshaus ${ }^{\mathrm{st}}$ and Porlland Cement Association v. Ruckelshaus, ${ }^{\mathrm{s5}}$ and Judge Bell's opinion in Texas $v$. EPA ${ }^{\mathrm{s} 6}$ represent a factual probing several times more detailed than the regulations at issue had received since they were first written.

The effect of such detailed factual review by the courts on the

82. The expert knowledge of different groups may of course fall in different areas. For example, the industry will probably know the most about how soon given control equipment can be put on line, while the EPA working group will probably know more about the adverse health effects of a given pollutant.

83. See generally Hamilton, supra note 9, at 1314 .

84. 478 F.2d 615 (D.C. Cir. 1973).

85. 486 F.2d 375 (D.C. Cir. 1973), cert. denied, 417 U.S. 921 (1974).

86. 499 F.2d 289 (5th Cir. 1974). 
portion of the agency subject to it is entirely beneficial.st It is a great tonic to a program to discover that even if a regulation can be slipped or wrestled through various layers of internal or external review without significant change, the final and most prestigious reviewing forum of all-a circuit court of appeals-will inquire into the minute details of methodology, data sufficiency and test procedure and will send the regulations back $^{88}$ if these are lacking. The effect of such judicial opinions within the agency reaches beyond those who were concerned with the specific regulations reviewed. They serve as a precedent for future rule-writers and give those who care about well-documented and well-reasoned decisionmaking a lever with which to move those who do not.

I see no way to relieve the courts, ultimately, of a substantial burden of factual inquiry. Courts alone have the time, ${ }^{89}$ the influence, and the freedom from ceremonial and "political" considerations that are necessary to a thorough, dispassionate and effective review of extremely complex and controversial matters. There is no reason, however, why the courts should have to bear as much of the burden of factual analysis as they have to date. In many instances the courts have done work that the agency itself should have done.

\section{A Procedural Approach to the Rulemaking Record}

Despite the excellent job the courts have done in reviewing the merits of EPA rules, it seems evident to those of us who observe

87. Certainly the decisions EPA made in response to these opinions on remand were far superior to the decisions that prompted them. Both Professor Williams and Judge Leventhal himself have suggested that El'A's decision after the remand in Internalional Harvester was something of a model for administrative agencies. See Williams, supra note 28, at 10 \& n.32, 26, 43-44; Leventhal, supra note 49, at 554-55. The D.C. Circuit recently sustained in all respects EPA's response to the remand order in Portland Cement. Portland Cement Ass'n v. Train, 513 F.2d 506 (D.C. Cir. 1975).

88. What matters, in my opinion, is whether the agency's faults are detected, more than what the court does after detecting them. Accordingly, in appropriate cases rigorous judicial review need not automatically lead to a stay of the regulation after remand. The court can leave the regulation in effect and so avoid damaging the agency's achievement of its mission, while the response to the remand is being prepared. Sec CPC Int'l, Inc. v. Train, 515 F.2d 1032, 1050-51 (8th Cir. 1975); Portland Cement Ass'n v. Ruckelshaus, 486 F.2d 375, 393-94 (D.C. Cir. 1973); Leventhal, supra note 49, at 539.

89. In saying this, I am not arguing against the present consensus that the courts of appeals are overworked. It is still trte, however, that court of appeals judges spend almost all their working day concerned with the intellectual merits of the controversies before them, and that these controversies are presented in relatively organized form. They are largely spared the endless round of political, organizational and simply ceremonial duties to which their counterparts in the executive and legislative branches must submit. My point ultimately is that if rulemaking records vere formalized to reduce inefficiency during review, court time spent in rigorously revicwing rulemaking would be time well spent. If an increase in judicial resources thereby became necessary, the costs involved would be well justified. 
them from the bottom that they aren't quite sure what they are looking at or what they should do to it. By and large, the obligation to undertake a fairly rigorous probing of the data and reasoning supporting a regulation has been accepted. Yet the supporting structure of trial-type hearings which used to precede such an inquiry has been largely swept away.

The central loss in discarding the adjudicatory model in favor of notice and comment rulemaking was not cross-examination ${ }^{90}$ or oral testimony in particular; rather it was the focused and defined record which all the procedures used in adjudication were intended to produce. This record served as the basis for decision both at the agency level and on review. There is at present in informal rulemaking no parallel requirement that the record certified to the court be the fruit of special procedures designed to produce it. As a result the courts are confronted with huge unwieldy records, and are forced ${ }^{91}$ to spend undue effort in weighting the parts of each record and extracting underlying reasons from the documents-jobs which the agencies should have done themselves.

\section{A. Two Views of the Rulemaking Record}

The generally accepted standard of review of informal agency rulemaking-the "arbitrary or capricious" test-makes no reference to the role of a record, and the courts and commentators have often said that the agency can rely on its general expertise in promulgating rules even when that expertise is not reflected in any record. ${ }^{92}$

Yet there is a record. Rule 17 of the Federal Rules of Appellate Procedure states that when review of a regulation is sought in a court of appeals, " $[\mathrm{t}]$ he agency shall file the record with the clerk of the court ... within 40 days after service ... of the petition for review

\section{See note 33 supra.}

91. The courts might attempt to require the attorneys to organize the record. This has been done in some cases. See, e.g., Texas v. EPA, 499 F.2d 289, 297 \& n.8 (5th Cir. 1974). But this device tends to run very soon into the Burlington Truck barrier against judging rules on the basis of the post hoc rationalizations of counsel. See Burlington Truck Lines v. United States, 371 U.S. 156 (1962); note 105 infra.

92. Angel v. Butz, 487 F.2d 260, 262-63 (10th Cir. 1973), cert. denied, 417 U.S. 967 (1974); Delaware Citizens for Clean Air, Inc. v. Administrator U.S. EPA, 480 F.2d 972, 976 (3d Cir. 1973); General Tel. Co. v. United States, 449 F.2d 846, 862 (5th Cir. 1974); California Citizens Band Ass'n v. United States, 375 F.2d 43, 54 (9th Cir.), cert. denied, 389 U.S. 844 (1967); Verkuil, supra note 28, at 187, 189; Note, supra note 25, at $784-85$. See also National Tire Dealers \& Retreaders Ass'n v. Brinegar, 491 F.2d 31, 41 (D.C. Cir. 1974) (accepting the statement, but finding allusions to expertise overwhelmed by other evidence). See generally Reich, The Law of the Planned Society, 75 YaLE L.J. 1227, 1242 (1966) ("Is not [agency] 'expertise' merely another term for knowledge of facts outside the record plus built-in predispositions?") 
..."93 The only guidance on what the record must contain is given in Rule 16 which states that " $[t]$ he order sought to be reviewed or enforced, the findings or report on which it is based, and the pleadings, evidence and proceedings before the agency shall constitute the record on review in proceedings to review or enforce the order of an agency." 94 The Advisory Committee's note adds that there "is no distinction between the record compiled in the agency proceeding and the record on review ... . The record in agency cases is thus the same as that in appeals from the district court-the original papers, transcripts and exhibits in the proceeding below."95 Plainly this language was drawn up with adjudicatory proceedings in mind. ${ }^{6 !}$ It does not address how the record in an informal rulemaking case should be assembled.

\section{1. "Historical" Records and "Procedural" Records}

In the review of agency actions less formal than full-scale adjudication, the guidelines followed in recent years have been those laid down in the Overton Park case, where the Supreme Court suggested an approach to the compilation of the record diametrically opposed to any thought that it reflect and follow the course of generally known and binding procedures. The Overton Court said that judicial review of the Secretary of Transportation's decision would have to be based "on the full administrative record that was before the Secretary at the time he made his decision."'97 Since the Court recognized a few pages earlier that there was no formal agency proceeding in decisions of this type for generating a record, the Court must have meant that the documents actually presented to the Secretary for his consideration would constitute the record. But this is based on the false assumption that all documents critical in reaching a given agency decision are in fact placed "before" the head of the agency, and that the internal procedures of the agency are firmly enough established and well enough observed to make location of these documents a rather

93. Federal Rule of Appellate Procedure 17, 389 U.S. 1087 (1968).

94. Federal Rule of Appellate Procedure 16(a), 389 U.S. 1087 (1968). This closely follows the language of 28 U.S.C, $\$ 2112(\mathrm{~b})$ (1970), which provides for the record on review of agency orders.

95. Advisory Committee Note, 28 U.S.C.A. Rule 16 (1969). The judicial review provisions of the Administrative Procedure Act provide that in applying any of the specified legal tests to any form of agency action "the court shall review the whole record or those parts of it cited by a party." 5 U.S.C. $\$ 706$ (Supp. III 1973).

96. The use of the term "order" in Rule 16 supports this conclusion, although the technicalities of the definitions used in the APA do not settle questions of appellate procedure.

97. 401 U.S. at 420 . 
ministerial act. ${ }^{98}$ Since these assumptions are not true, the only way to assemble a record that gives the court a picture of what the agency actually thought and considered is through an ad hoc effort to reconstruct what happened in a particular case. To do this, the documents that have passed through the formal internal procedures of the agency must be examined. But since these formal procedures are scarcely the exclusive vehicles for considering issues within an agency, much else must be included as well. I call this effort at post hoc reconstruction of what actually happened a "historical" approach to compiling a record..$^{09}$

Courts and commentators have often endorsed a historical approach. ${ }^{100}$ It does not correspond, however, to the way records for decision and judicial review are generated in trial courts and agency adjudication. As the committee note to Rule 16 suggests, a record

98. "The Court in Overton Park seemed to assume that there was somewhere an claborate administrative record which could easily be produced." Nathanson, supra note 31 , at 723 .

99. However, since little effort is typically spent on assigning weights to the documents or attempting to place them in the context of a narrative, "archive" might be more descriptive of what is generally produced.

100. See Camp v. Pitts, 411 U.S. 138, 142-43 (1973); Amoco Oil Co. v. EPA, 501 F.2d 722, 729 11.10 (D.C. Cir. 1974); Industrial Union Dep't v. Hodgson, 499 F.2d 467, 474 (D.C. Cir. 1974); Texas v. EPA, 499 F.2d 289, 297 (5th Cir. 1974); Consumers Union of United States, Inc. v. Consumer Product Safety Comm'n, 491 F.2d 810, 812 (2d Cir. 1974); Appalachian Power Co. v. EPA, 477 F.2d 495, 507 (4th Cir. 1973); Scalia \& Goodman, Procedural Aspects of the Constumer Product Safety Act, 20 U.C.L.A.L. REv. 899, 933-36 (1973); Verkuil, supra note 28, at 204 ("One can conclude that 'record' now means whatever the agency produces on review.") See also id. at 228, 246; Note, supra note 25, at 802 n.126.

Of course the device of review on a historical record has not been confined to rulemaking. Courts reviewing less formal agency action have also often called for the "full administrative record" to be produced. This was true in Overton Park itself, and also in the other leading Supreme Court case on that point, Camp v. Pitts, 411 U.S. 138 (1973) (refusal to grant national bank charter). See Rhode Island Consumers' Council v. FPC, 504 F.2d 203, 209-10 (D.C. Cir. 1974) (Leventhal, J.) (FPC approval of nonunanimous settlement of agency adjudicatory proceeding); Bradley $v$. Weinberger, 483 F.2d 410, 414-15 (lst Cir. 1973) (FD.1 labeling order); Silva v. Lynn, 482 F.2d 1282, 1283.84 (1st Cir. 1973) (NEPA statement); Aguayo v. Richardson, 473 F.2d 1090, 1103 (2d Cir. 1973) (Friendly, J.), cert. denied, 414 U.S. 1146 (1974) (federal approval of experimental state work requirements for recipients of welfare federally funded in part). In Aguayo Judge Friendly said:

"[C]onsideration of these claims . . t takes us into a type of judicial review considerably more difficult to define and exercise than traditional review of administrative action. We have here no adversary hearing, no record, no statement of the grounds for the Secretary's action, except as these may be inferred from the papers on which he acted and from the largely unhelpful documents prepared specifically for this litigation.

473 F.2d at 1103.

The criticisms made in this article of the "historical" record, and the suggestion that administrative records be defined in procedural terms, would seem to be applicable to such informal actions as well. For a case where a court reviewing informal action required certain steps to be taken to generate and organize a "record," see Oljato Chapter of the Navajo Tribe v. Train, 515 F.2d 654, 665-67 (D.C. Cir. 1975). 
is normally defined as the material which has been accepted under a given obligatory set of procedures. I call this a "procedural" approach to compiling the record. A trial court record is "procedural" since it consists of everything that has been properly placed in evidence under defined rules of admissibility during the course of the trial.

\section{The Recommendations of the Administrative Conference}

Unfortunately, the most authoritative recent statement on what rulemaking records should contain completely fails to grasp the distinction between a "procedural" and a "historical" approach. In consequence, if followed it would not only perpetuate the present use of historical records; in some respects it would make them worse. The Administrative Conference of the United States ${ }^{101}$ has recommended ${ }^{102}$ that the record for judicial review of informal rulemaking should consist of (1) the notice of proposed rulemaking and any documents referred to in it; (2) the comments and documents submitted by interested persons; (3) transcripts of any hearings held in the course of the rulemaking; (4) reports of any advisory committees; (5) the agency's concise general statement or final order and any documents referred to in it; and (6) other factual information "not included in the foregoing that was considered by the authority responsible for promulgation of the rule or that is proffered by the agency as pertinent to the rule."103

The first five items cause no difficulty. Both under a historical approach to the record and under a procedural approach, they would certainly be included. But the first clause of the sixth recommendation comes down squarely on the side of the historical approach by explicitly recognizing the agency's right to include in the record whatever documents it "considered"-even if they arose outside the APA notice and comment procedures. ${ }^{104}$ In addition, in defining the record as what was considered by the "authority responsible for promulgation of the rule," the Administrative Conference misstates the nature of

101. The Administrative Conference of the United States is a large body of temporarily appointed experts on administrative law, assisted by a small permanent staff of civil servants, which is supposed to study the full range of agency procedures and make recommendations for legislative changes. See 5 U.S.C. $\$ \$ 571-76$ (Supp. III 1973).

102. Recommendation No. 74-4, Preenforcement judicial review of rules of general applicability, 1 C.F.R. $\$ 305.74-4$ (1975) (adopted May 30-31, 1974).

103. I C.F.R. $\$ 305.74-4(1)(4)(1975)$.

104. Indeed the recommendation could be read as refusing to adopt the rule laid down in Portland Cement Ass'n v. Ruckelshaus, 486 F.2d 375 (D.C. Cir. 1973), that highly relevant factual materials be disclosed to interested parties for comment before the agency may rely on them. See p. 75 infra. The first five categories all refer to information which will have been disclosed to the public. The last category can casily be read as a "residual" onc covering information that was not submitted to this process. 
rulemaking. Only a very few, highly controversial issues can hope to receive detailed personal attention from the administrator of a busy agency, be he or she ever so competent. In all other cases, no single authority passes judgment on the rule. Different parts of the agency work on different parts of the rule, or on the same part from different angles-and the rule emerges. It follows from the lack of any meaningful central "authority" that the phrase "considered by the authority" also loses meaning, and sets no clear boundary to the size or content of the record. Given the diffuse nature of rulemaking, it will be a rare document that cannot claim to have been considered somewhere to some extent by someone in connection with the rulemaking, and a document almost as rare that will have received the personal attention of the administrator.

The other test suggested by the Administrative Conference for including documents in the record-whether they are "proffered by the agency as pertinent to the rule"-is even worse. It breaks free of the restriction implicit even in the historical approach that the record certified to the court should reflect what the agency actually weighed and evaluated in some manner at the time of the rulemaking. Indeed, it would apparently allow the agency to include whatever it thinks would help support its actions once litigation has begun. ${ }^{105}$

The relevant questions, which the Administrative Conference recommendation ignores, thus are the quality of the consideration given the documents involved and the manner in which they are determined to be relevant. Instead, the recommendation follows Overton Park in assuming falsely that all of the internal decisionmaking procedures of the agencies are (1) satisfactory and (2) given.

105. The cases have long since established that an agency action may not be upheld for reasons put forward for the first time by counsel during judicial review, rather than by the agency itself. Burlington Truck Lines v. United States, 37I U.S. 156, 168-69 (1962); International Harvester Co.v. Ruckelshaus, 478 F,2d 615, 632 (D.C. Cir. 1973). This has come to be known as the Burlington Truck rule.

Yet at the same time it is relatively easy for the agency to supplement the record unilaterally after rulemaking is over and judicial review has begun. Under the historical approach to compiling a record it is hard to show that any documents so offered do not qualify for inclusion, at least if they predate the final regulation. See Amoco Oil Co. v. EPA, 501 F.2d 729, 729 n.10 (D.C. Cir. 1974). Indeed, if some form of public comment is invited before the record is supplenented, supplementing the record is affirmatively encouraged by both International Harvester Co. v. Ruckelshaus, 478 F.2d 615, 633 (D.C. Cir. 1973) and Portland Cement Ass'n v. Ruckelshaus, 486 F.2d 375, 394 (D.C. Cir. 1973).

Despite this, I believe that agency action to supplement the record in whatever manner (short of a full reproposal) after the main rulemaking has closed carries with it several of the same dangers that led to the Burlington Truck rule. These actions frequently reflect the views of agency counsel at a time when their influence has been magnified by the onset of litigation, and do not mean that those who actually originated the rule are being forced by litigation to have second thoughts about what they did. 


\section{Procedural Records in the Courts}

A few courts have made an effort to solve some of these problems by defining the record for judicial review of informal rulemaking in procedural terms. In Automotive Parts and Accessories Corp. $v$. $B o y d,{ }^{106}$ a case involving the promulgation of auto safety standards, the D.C. Circuit stated that the record for judicial review "consist[ed] of the submissions made in response to the invitations issued for written comments." Since the record plainly also must include the proposed rule to which the submissions were directed, and the final rule which is the subject of the petition, the thrust of Automotive Parts is to define the record in terms of the three stages of rulemaking required by $\S 553$ of the APA-proposal of the rule, receipt of public comments and final promulgation, together with a response to comments.

Yet despite Automotive Parts, no court has actually adopted a procedural approach to the extent of excluding material that has not been included in the three steps of $\$ 553$ notice and comment procedures. This drives both the agency and the plaintiff challenging the rule (typically the industry being regulated) to try to get as many documents into the record as possible. In that process, any real attempt at "historical" reconstruction is soon lost or blurred.

\section{B. EPA Practice in Compiling Rulemaking Records}

When a petition for review of an EPA regulation is filed, the first job of the EPA lawyer assigned to the case is to compile the record or oversee its compilation. One knows from the start that certain documents must go in even under a strict procedural approach. These include the notice of proposed rulemaking and any technical support document cited in it, the public comments, the transcript of any hearings that may have been held and, of course, the final rule itself. In virtually every case, however, the agency has numerous other documents relevant to the rulemaking in one way or another. The pressure to put these documents in the record as well is irresistible, once they

106. 407 F.2d 330, 336 (D.C. Cir. 1968). See also Rodway v. United States Dep't of Agriculture, 514 F.2d 809, 817 (D.C. Cir. 1975) ("The whole record in an informal rulcmaking case is comprised of comments received, hearings held, if any, and the basis and purpose statement."); Buckeye Power, Inc. v. EPA, 481 F.2d 162, 171 (6th Cir. 1973) ("The Administrator built no record in approving or disapproving the state plans. He took no comments, data, or other evidence from interested parties, [pursuant to 5 U.S.C. $\$ 553$ ], nor did he articulate the basis for his actions."); Phillips Petroleum Co. $v$. IPC, 475 F.2d 842, 850 (10th Cir. 1973), cert. denied, 414 U.S. 1146 (1974). 
come to the attention of the supervising attorney. ${ }^{107}$ If they favor the agency, they certainly can't hurt and might as well go in. If they are damaging, they also must go in once the lawyer handling the case has discovered them, both out of simple honesty and because nothing could prejudice the agency's position more irreparably in the eyes of the courts than to be caught suppressing information. The agency's presumption must be that any suppression will be discovered. Agencies leak, and in addition many petitioners have begun to make broad requests under the Freedom of Information Act (FOIA) ${ }^{108}$ for all documents relevant to a particular rulemaking.

The newly relaxed burden of proof requirements and the "bad faith" exemption to the Morgan test also contribute to the pressure for long records. If agency action is increasingly based on policy judgments about competing risks rather than on conclusive facts, it is hard to see how the agency can refuse to give in some detail a history of how that judgment was formed as one means of checking its validity. As for "bad faith," EPA's experience has been that its presence is far more often suggested by industry counsel than believed in, and far more often believed in than actually present. In most cases, then, simple disclosure of the relevant documents by the agency will be a conclusive response. And, against that background, any failure to make such disclosure automatically tends to raise some question about motives.

The agency lawyer may find most relevant documents or copies of them in one spot within the office of primary interest. But very often, this does not happen. ${ }^{109}$ Program offices themselves are often diffuse. In addition, complex regulations stop in several places as they are developed. In a geographically spread-out agency like EPA, ${ }^{110}$ these are

107. However, as a general rule documents generated during the OMB review process are not included in the record. This would include not only comments to EPA from other agencies, but also the often cxtensive comments sent by regulated parties and others to OMB directly.

108. 5 U.S.C. $\$ 552$ (Supp. III 1973).

109. The pattern in which these documents turn up provides a highly sensitive guide to the coherence of the rulemaking. If most relevent documents or copies of them are found in one spot, and that is one particular location within the program office or offices mainly responsible for the rule, there is at least some assurance that agency consideration of the problems has been centered there and that it was at least potentially possible for reviewing offices inside the agency to look at the background of the rulemaking as a whole.

110. EPA's headquarters and top officials are located in Washington, D.C. Some headquarters supporting staff is still across the Potomac in the Virginia suburbs. Ten regional offices-in Boston, New York, Philadelphia, Atlanta, Dallas, Kansas City, Chicago, Denver, San Francisco, and Seattle-are responsible for implementing and in large measure for developing EPA programs in their respective areas of the country. They often take a lively interest in the development of regulations. Finally, large 
often in different parts of the country. Often each office that reviews the rule speaks on the basis of its own separate documentation. Yet this documentation, though it formed that office's thinking, may not be forwarded in its entirety to the lead office along with the recommendations that were based on it. Such documents, when discovered in compiling the record, must also be made a part of it. Despite these difficulties, the obligation to act in good faith at least tells the agency lawyer where to stop. If all the program offices have been checked for relevant documents, good faith at least is satisfied.111

Industry lawyers will look more exclusively to the results which they can obtain by making additions to the record. Thanks to recent decisions which limit the extent to which an agency can support its actions by including in the record material the other side has not seen before, ${ }^{112}$ their main fear probably is not that an agency will put forward new material to support its own case. Rather they will worry that material which supports their own position or makes the agency look bad will be withheld. Accordingly, industries affected by EPA rulemaking frequently invoke the Freedom of Information Act as a discovery device. ${ }^{113}$

scientific and engineering staffs, whose work is often vital to a rule, are located in Durham, North Carolina; Cincinnati, Ohio; Ann Arbor, Michigan; Duluth, Minnesota; Las Vegas, Nevada; and Corvallis, Oregon.

111. Unfortunately, the immense job of searching the files of all relevant offices to assemble a record must generally be done in a hurry, and much of it is necessarily delegated to persons remote from the litigation and even from the rulemaking. All too often, then, this effort does not disclose all the relevant documents.

When relevant papers adverse to the agency turn up after the initial record has been filed, there is really no alternative to filing them as a supplemental record. If they are favorable, the agency will face the unpalatable choice of either leaving the court in ignorance of their existence or filing a supplemental record that will inevitably look like a last-minute effort to reinforce a shaky case. Such embarrassments to lawyers apart, however, these events raise some question about the completeness of the "historical" archive that typically gets filed in rulemaking cases.

112. See pp. 75-76 infra.

113. One such request was submitted on behalf of the Utility Water Act Group, an association of electric power companies, in connection with EPA's development of effluent guidelines for steam electric power plants under the Federal Water Pollution Control Act. After describing the information in general terms, the letter goes on to state:

We request all material (1) without regard to whether it is fact, opinion or recommendation, (2) whatever its form, whether report, study, survey, analysis, memorandum, letter, working papers, or other, (3) irrespective of its type, whether scientific, economic, technical or the like, (4) without regard to its source, whether from an employee of EPA or any other governmental entity, from the consultants of any governmental entity, from groups established to advise governmental bodies, such as EPA's Effluent Standards and Water Quality Information Advisory Committee, or from any element of the public, not least of all industry and chsironmentalists, and (6) [sic] whatever the level at which the material is sent fiom or received by EPA.

We request all matcrial relating to regulations for steam electric power plants 
For a variety of reasons, this tactic has worked fairly well for those who use it, even though the statute probably wasn't intended for that purpose. ${ }^{114}$ One is the same need of the agency to appear candid that makes its own contribution to the record grow. Another is that many documents that probably could be withheld simply aren't worth fighting about, particularly given the amount of work such a fight can entail. Disclosure of such documents harmless to the agency's position leads naturally to the inference that documents which the agency might withhold are the reverse, and so pressure increases for disclosure of all documents to reduce suspicion. Finally, the agency usually will be reluctant to start a procedural fight that might delay a decision on the merits, ${ }^{115}$ because of its general interest in speedy review. A victory or partial victory in court allows programs to move ahead with much more authority; defeats ideally should be suffered early in a program's life, so that not much time is lost.

But even if documents are disclosed to the industry, it does not automatically follow that they will be included in the record. If they are made available in time for the industry to resubmit them as part of the comments on the proposed rule, then they will become part of the record by definition. But if the industry waits until the rule is formally proposed to file an FOIA request, this may not be possible; the time limit for disclosure under the 1974 amendments to the Freedom of Information Act ${ }^{116}$ is only slightly shorter than the typical comment period on a rule. ${ }^{117}$ Indeed, industries often do not think to file

under the pertinent FWPCA provisions, even material which EPA regards as background data, working papers and drafts, or as having no merit.

Letter from George C. Freeman, Jr., Counsel for the Utility Water Act Group, to Ann Dore, Director, Office of Public Affairs, EPA, May 29, 1974, at 6-7 (on file with Yale Law Journal). The EPA staff lawyer who handled this request estimates that some 100,000 pages of documents were disclosed under it.

114. NLRB v. Sears, Rocbuck \& Co., 95 S. Ct. 1504,1513 n.10 (1975) ("The Act is fundamentally designed to inform the public about agency action and not to benefit private litigants."); Renegotiation Bd. v. Bannercraft Clothing Co., 415 U.S. 1, 24 (1974) ("Discovery for litigation purposes is not an expressly indicated purpose of the Act.") Sce also Bristol-Myers Co. v. FTC, 424 F.2d 935, 938-39 (D.C. Cir.), cert. denied, 400 U.S. $824(1970)$ (appears to accept view that an agency under the Freedom of Information Act may withhold documents cited as support for a rule); Sterling Drug, Inc. v. FTC, 450 F.2d 698, 705.08 (D.C. Cir. 1971).

115. This motive has its effect even though the courts have been unwilling to enjoin agency action pending the outcome of litigation on a related Frecdom of Information Act request. See Renegotiation Bd. v. Bannercraft Clothing Co., 415 U.S. 1, 24 (1974); National Cable Television Ass'n, Inc. v. FCC, 479 F.2d 183,185 n.2 (D.C. Cir. 1973).

116. Act of Nov. 21, 1974, l'ub. L. No. 93-502, 88 Stat. 1561.

117. Under the 1974 amendments, an agency has an outside limit of 50 working days to act on a request for information. See Act of Nov. 21, 1974, § (c), Pub. L. No. 93-502, 88 Stat. 1561. Further delay would be possible if the agency forced the party invoking the FOIA to litigate. Proposed rules typically have a comment period of 60 or 90 calendar days. 
an FOIA request until the beginning of litigation. Cases often arise, then, where the agency has no clear legal obligation to include in the record documents that the industry would like to see there. ${ }^{118}$ If the agency firmly refused to include them, the industry might be willing to litigate the question. In practice, however, such disputes seldom become major or last long. The same pressures that make for long initial records, and for full compliance with FOIA requests, make it seem pointless to fight when the inclusion of additional documents in the record is suggested. At every stage, then, the tendency of the record is to increase in length and become less organized. Factual materials, documents describing the development of policy, and documents included simply to quiet suspicions of bad faith will all be jumbled in together.

\section{Problems of the Current Approach to Compiling the Record}

The unwieldy and disorganized records created through this process must be a plague to the courts. Several courts have commented adversely on the sheer burden of extra work created. ${ }^{110}$ This work consists of more than just assimilating and cross-referencing a large body of material. The chaos in records certified to reviewing courts has affected the process of judicial review itself, ${ }^{120}$ in a way that increases the burdens placed on the courts and decreases the useful discipline imposed on the agency.

118. The documents may be viewed by the agency, for cxample, as raising matters which have been definitely settled already, or which were not addressed during the rulemaking, or which can only be litigated in another forum. The petitioners in Texas v. EPA, 499 F.2d 289, 294 n.4 (5th Cir. 1974), for example, attempted to have includcd in the record numerous documents relating to the proper techniques for measurement of ambient levels of photochemical oxidants, even though the air quality standard itself prescribes a measuring technique. EPA refused on the ground that the measuring technique is an integral part of the air quality standard which in turn, under $\$ 307$ of the Clean Air Act, 42 U.S.C. $\$ 1857 \mathrm{~h}-5$ (Supp. III 1973), can only be reviewed in the D.C. Circuit.

119. Industrial Union Dep't v. Hodgson, 499 F.2d 467, 474 (D.C. Cir. 1974) ("In substantial remaining part, however, [the record] consists of a melange of written statements, letters, reports, and similar materials ... untested by anything approaching the adversary process."); Texas v. EPA, 499 F.2d 289, 308 n.3I (5th Cir. 1974); id. at 321-22 (Clark, J., concurring). See also Florida Peach Growers Ass'n v. United States Dep't of Labor, 489 F.2d 120, 129 (5th Cir. 1974) ("The state of the record in this case is one of the difficulties besetting our review function."); Florida Peach Growers, however, involved an OSHA temporary emergency standard promulgated without proposal or a comment period. In addition, EPA attorneys in at least two cases I am familiar with have been asked by circuit judges during litigation to explain what the court should do with the record.

120. "The type of administrative proceeding and the form of record it produces will influence the method of review." Florida Peach Growers Ass'n v. United States Dep't of Labor, 489 F.2d 120, 128 (5th Gir. 1974). See Chicago v. FPC, 458 F.2d 731, 743-44 (D.C. Cir. 1971). 


\section{The Impact on the Courts}

Whatever the standard of review, it has been accepted since the first case of Securities and Exchange Commission v. Chenery Corp. ${ }^{121}$ that the validity of an agency decision depends not only on whether there exist legally adequate reasons for the decision but on whether the reasons offered by the agency are among them. A closely related principle is that where no reason at all has been given, the agency action must not be sustained. In Judge Leventhal's words, the agency's decision "must be explained, not merely explainable."122

But explained where? This question takes on particular point when a court is faced with a record containing a great many documents prepared within or for the agency whose action is under review, but which have been considered and endorsed to widely varying degrees by different groups in the agency. ${ }^{123}$ At present, a fairly rigorous approach prevails, under which the necessary articulation of reasons must appear in the preamble to the promulgated rule or in some other document of equally formal standing. ${ }^{124}$ But many courts are still content to plow through the certified papers to make their own judgment as to whether what happened was rational; agency actions have been upheld where the justification appeared in factual studies, contractors' reports, or documents prepared by subordinate agency personnel and not approved by or even presented to their superiors. ${ }^{125}$

To some extent, as Judge Friendly has noted, ${ }^{\mathbf{1 2 6}}$ this tendency is probably inevitable. The impulse for a court to uphold as much of a rule as seems justified from an independent examination of the record can be very strong, particularly in important, attractive or clear cases. Such a course may well seem more responsible and more in accord with the governing congressional purpose than upsetting a whole program because some of the more or less apparent reasons be-

121. 318 U.S. 80 (1943) (Chencry I).

122. Environmental Defense Fund v. EPA, 465 F.2d 528, 539 (1972) (Leventhal, J.).

123. For a case with a record reflecting this tendency, see the panel opinion (since vacated) in Ethyl Corp. v. EPA, 7 BNA Environ. ReP. CAS. 1353 (D.C. Cir., Jan. 28, 1975), vacated on order granting rehearing en banc, No. 73-2205 (D.C. Cir., Mar. 17, 1975), reheard en banc (D.C. Cir., May 30, 1975).

124. Associated Indus. of N.Y. State, Inc. v. United States Dep't of Labor, 487 F.2d 342, 353 (2d Cir. 1973) (Friendly, J.); Dry Color Mffrs. Ass'n v. United States Dep't of Labor, 486 F.2d 98, 105-07 (3d Cir. 1973); Kennecott Copper Corp. v. EPA, 462 F.2d 846, 849 (D.C. Cir. 1972) (Leventhal, J.). But see Dry Color Mfrs. Ass'n v. United States Dep't of Labor, supra at 109-10 (McLaughlin, J., dissenting).

125. See Texas v. EPA, 499 F.2d 289 (5th Cir. 1974); Delaware Citizens for Clean Air, Inc. v. Administrator U.S. EPA, 480 F.2d 972, 977 (3d Cir. 1973); Bunny Bear, Inc. v. Peterson, 473 F.2d 1002 (1st Cir, 1973). See also Camp v. Pitts, 411 U.S. 138 (1973).

126. Friendly, Chenery Revisited: Reflections on Reversal and Remand of Administrative Orders, 1969 Duke L.J. 199. 
hind it were not formally provided. Indeed, this temptation may have its effect even where the court does not openly yield to it. A judge-may find that a required standard of factual support has been met and reasons sufficiently articulated even in cases where that might not be apparent to an outside observer.

But this tendency is reinforced by the open ended and disorganized way in which rulemaking records are compiled at present. Once documents find their way into the record, the parties will cite and discuss them, creating pressure on the court to consider them even where they were not discussed by the agency or the parties during the rulemaking. ${ }^{127}$

Such ad hoc review has another consequence. It tends to erode the Morgan bar against probing the actual mental processes of the decisionmaker. ${ }^{128}$ That rule was announced in the course of reviewing an agency decision taken after a formal hearing. Indeed, to a great extent it only makes sense when a decision has been shaped and structured by formal procedures. Where such procedures are comprehensive and binding enough to give substantial protection against arbitrary or unreasoned action, judicial review can be limited to what has passed through them and still be effective. But if the procedures are not satisfactory, pressure to reach beyond them to the actual "mental process" of the agency will result.

Some probing of mental processes is implicit in a historical record, which by its nature is supposed to reflect the internal workings of the agency in a way that a trial record does not reflect the internal workings of a court. The various agency documents, with dates, authors and addresses, do in fact provide a fair amount of material for such an examination. Yet any suggestion that the Morgan rule may be inapplicable in judicial review of informal action has been rejected by the courts. ${ }^{129}$ The result has been to saddle the courts with a "mental processes" rule which is only acceptable if decisionmaking procedures are satisfactory. At present there are no such procedures, and the records submitted by their nature invite the kind of review

127. See South Terminal Corp. v. EPA, 504 F.2d 646, 666 (1st Cir. 1974), where the court, in remanding portions of the Boston transportation control plan to EP.I for further technical analysis, said:

It is perhaps paradoxical that the necessity of a further hearing arises from the fault not of EPA but of petitioners, who . . . were remiss in not presenting the questions now troubling us at the original [informal administrative] hearing. . . . Were the proceeding of less importance to the public at large we might decline to entertain the objections at this late stage.

128. See note 53 supra.

129. See National Nutritional Foods Ass'n v. FDA, 491 F.2d 1141, 1144-45 (2d Cir.) (Friendly, J.), cert. denied, 419 U.S. 874 (1974). 
that Morgan rejected. It follows that greater formality in rulemaking is necessary to make the Morgan test appropriate.

\section{The Impact on Agency Rulemaking}

Section 553 of the APA requires that an agency incorporate in the rules which it adopts "a concise general statement of their basis and purpose."130 This requirement is met by "preambles" to proposed and final rules which often incorporate by reference technical support documents. As discussed below, the degree of detail required in these documents has become much greater than the language of the APA might initially suggest. ${ }^{131}$ Simply adding detail, however, without procedural reforms, will not lead to satisfactory results under a system of ad hoc judicial review.

A requirement that an agency be judged on a single, comprehensive, detailed justification for its decision, prepared at the time when it promulgates a rule, would have several potentially beneficial effects. It would force the various subunits within the agency to pursue their differences on questions of fact, interpretation or policy until they could be resolved. It would force the agency to choose between alternative data, theories and methodologies and create a coherent case upon which scrutiny by the courts can be focused. Unfortunately, these benefits cannot be completely realized under the present system of historical records and ad hoc judicial review. Under such a system, the statements drafted and published as justifications for rules are not completely binding on the agency. The stated justifications for a rule will be less comprehensive and thoughtful if there is the possibility that they could be supplemented with other material on review. The commitment of the agency to a given argument or to the relative assignments of importance given to various documents obviously means less if the agency lawyer can persuade a court to accept a justification built on anything which the "agency" "considered."

Thus, carelessness by the subunits of the agency in drafting the preamble and technical support documents is not necessarily perceived as fatal to the success of the rule on review. As a result the offices within an agency which are most familiar with the basis for the rule and which are most capable of stating the strongest case for its adoption do not have the maximum incentive to expend significant effort in doing so. As long as there is ad hoc review of historical records, agency lawyers will continue to discover during judicial review that

130. 5 U.S.C. $\$ 553$ (c) (Supp. III 1973).

131. See p. 75 infra. 
important material has been underemphasized or overlooked in the supporting documents drafted by these groups. There is no assurance that strong supporting arguments which were developed by one office will find their way into the stated support for the rule. Opposing data and argument which could have been answered may not be answered thoroughly. And most importantly, this lack of discipline may cause an agency to promulgate a rule which with a few changes would be better able to withstand industry attacks and judicial review. Accordingly what is needed is not just more detail in rulemaking, but a set of procedures for presenting and organizing that detail in a principled way before a rule is promulgated.

\section{Making the Rulemaking Record Binding}

EPA rulemaking does not suffer from a lack of formal mechanisms for criticism of an initial proposal. These already include the working groups, steering committee, OMB, public comment and informal meetings. But because the information used in rulemaking and the conclusions reached are never formally entered into a binding record, this criticism does not probe deeply enough in all cases. ${ }^{132}$ Such binding procedures for compilation of a record during rulemaking would encourage the analysis of problems in greater depth even before regulations are challenged by interested parties in the courts. This section examines how the courts have begun working out such procedures and how they should finish the job.

\section{A. Portland Cement}

Taken on its face, the notice and comment process outlined in $\$ 553$ of the APA is undemanding. As the number and importance of the subjects addressed by rulemaking have increased, Congress in the particular regulatory statutes increasingly has called for use of additional procedures. ${ }^{133}$ But even more important, the courts have begun to read new procedural requirements into the text of $\$ 553$ itself. These new requirements, together with substantive judicial review, are be-

132. For this reason, I see little hope of better rulemaking from EPA's decision to write NEPA environmental impact statements for its major regulatory activities. 39 Fed. Reg. 16186 (1974). The NEP.A analysis-which calls into play a statute whose purpose is to provide wider perspective-is a mechanism for increasing the breadth of analysis, not for ensuring that the analysis probes deeply enough.

133. These can include requirements for consultations with other federal agencies or with advisory committees, informal legislative-type hearings, requirements that even rules promulgated by notice and comment procedures be revicwed under a substantial evidence test, and retention of a veto power over each rule by Congress. See Hamilton, supra note 9 , at $1313-30$. 
coming the most effective and reliable safeguards against arbitrary regulation in the whole rulemaking process. ${ }^{13 *}$

The foundations here have been laid down in a series of opinions by Judge Leventhal. The cornerstone is Portland Cement Association v. Ruckelshaus, ${ }^{135}$ though Kennecott Copper Corp. v. EPA, ${ }^{136}$ and International Harvester Co. v. Ruckelshaus ${ }^{137}$ are also important. These cases impose the following procedural standards for rulemaking.

First, both the essential factual data on which the rule is based and the methodology used in reasoning from the data to the proposed standard must be disclosed for comment at the time a rule is proposed. To the extent they are not available at that time, they must be disclosed when they become available. ${ }^{138}$ Second, the agency's discussion of the basis and purpose of its rule-generally contained in the "preambles" to the notices of proposed and final rulemaking and in the accompanying technical support documents-must detail the steps of the agency's reasoning and its factual basis. ${ }^{139}$ Third, significant com-

134. Although the opinions imposing these new procedural requirements should have a persuasive impact on other courts, as yet these reforms are the law only in the D.C. Circuit. By no means are these reforms an accomplished fact for all federal administrative agencies. Exclusive venue in the D.C. Circuit is relatively rare even at EPA. The Federal Water Pollution Control Act nowhere provides for it. And though the Clean $\mathrm{Air}$ Act does call for it in a number of major cases, see 42 U.S.C. $\$ 1857 \mathrm{~h}-5$ (b) (Supp. III 1973), review of state implementation plans-by far the largest category of cases-generally takes place in the federal circuit which includes the state involved. Only when a "national" issue affecting the whole country is involved may the case be transferred to the D.C. Circuit. See Dayton Power \& Light Co. v. EPA, No. 74-2297 (6th Cir., June 16, 1975).

135. 486 F.2d 375 (D.C. Cir. 1973), cert. denied, 417 U.S. 921 (1974).

136. 462 F.2d 846 (D.C. Cir. 1972).

137. 478 F.2d 615 (D.C. Cir. 1973).

138. It is not consonant with the purpose of a rule-making proceeding to promulgate rules on the basis of ... data that, [in] critical degree, is known only to the agency.

....

In order that the rule-making proceedings to determine standards be conducted in orderly fashion, information should generally be disclosed as to the basis of a proposed rule at the time of issuance. If this is not feasible, . . . information that is material to the subject at hand should be disclosed as it becomes available, and comments received, even though subsequent to issuance of the rule-with court authorization, where necessary.

Portland Cement Ass'n v. Ruckelshaus, 486 F.2d 375, 393-94 (D.C. Cir. 1973). Similarly, in International Harvester Co. v. Ruckelshaus, 478 F.2d 615, 631-32 (D.C. Cir. 1973), the court, though declining to hold that EPA's failure to allow auto companies to comment on the technical assumptions or methodology used in the agency's prediction that auto emission standards could be met was a violation of any specific provision of law, did note that this failure presented "[a] . . . serious problem, at least from the point of view of an informed decision-making process." The court required that "the parties should have opportunity on remand to address themselves to matters not previously put before them by EPA for comment, including [the methodology used in making the original decision.]" Id. at 649 .

139. [S] ection 111 of the Clean Air Act, properly construed, requires the functional equivalent of a NEPA impact statement. ...

....

... To the extent that EPA is aware of significant adverse environmental conse- 
ments received during the public comment period must be answered at the time of final promulgation. However, comments must meet a standard of detail equal to that required of the agency in promulgating its rule before they will be considered significant. ${ }^{100}$ Fourth, only objections to the regulations which were raised with some specificity during the public comment period, and to which the agency thus had an opportunity to respond, may be raised during judicial review. ${ }^{141}$

Although these procedures may be new to agency rulemaking, the ideas behind them are not new at all. In each case, the "new" procedure simply transposes to rulemaking principles well established and accepted where agency adjudication is concerned. Both cases and statutes have long demanded, of course, that an opinion in agency adjudication articulate the reasons for the action and respond to significant objections, however much that requirement may have been honored in the breach. ${ }^{142}$ That all material information must be dis-

quences of its proposal, good faith requires appropriate reference in its reasons for the proposal and its underlying balancing analysis.

Portland Cement Ass'n v. Ruckelshaus, 486 F.2d 375, 384-86 (D.C. Cir. 1973).

[A] comment on the proper use of scientific literature may be in order. If such literature is relied upon, the agency should indicate which particular findings of that literature are significant. A generalized reference, to a work as a whole, will avail the agency little if a problem arises on judicial review.

Id. at 400. In an earlier case, Judge Leventhal noted:

Inherent in the responsibility entrusted to this court [to review EPA standards] is a requirement that we be given sufficient indication of the basis on which the Administrator reached [his judgment] so that we may consider whether it embodies an abuse of discretion or error of law.

Kennecott Copper Corp. v. EPA, 462 F.2d 846, 849 (D.C. Cir. 1972) (footnote omitted). Although the court also said that "[w]e are not to be taken as specifying that the agency must provide the same articulation as is required for orders or regulations issued after evidentiary hearings," $i d$., this qualification, at EPA at least, has had much less influence than the demand for more explanation quoted above.

140. Manufacturers' comments must be significant enough to step over a threshold requirement of materiality before any lack of agency response or consideration hecomes of concern. The comment cannot merely state that a particular mistake was made in a sampling operation; it must show why the mistake was of possible significance in the results of the test.

Portland Cement Ass'n v. Ruckelshaus, 486 F.2d 375, 394 (D.C. Cir. 1973). In that opinion the court also identified points raised in industry comments that EP.I had not responded to satisfactorily and would have to address on remand. Id. at $396-99$.

141. [C]hallenges to standards must be limited to points made by petitioners in agency proceedings. To entertain comments made for the first time before this court would be destructive of a meaningful administrative process.

Id. at 394. See note 150 infra.

142. See Florida v. United States, 282 U.S. 194 (1931) (Hughes, C.J.); Panama Ref. Co. v. Ryan, 293 U.S. 388, 447 (1935) (Cardozo, J., dissenting, noted in dictum that a "quasi judicial officer" or an "administrative agency" "may be required by reviewing courts to express their decision in formal and explicit findings to the end that review may be intelligent.")

Where formal administrative hearings are concerned, the Administrative Procedure. Act requires "[a]ll decisions, including initial, recommended, and tentative decisions" to " include "findings and conclusions, and the reasons or basis therefor, on all the material 
closed seems necessary to the idea of decisionmaking on a record, and has long been explicitly required. ${ }^{143}$ Finally, the rule that objections must be raised before the initial decisionmaker or not at all was settled for trial courts before there were agencies, and was adopted early in the history of administrative adjudication. ${ }^{144}$

The application of these requirements to informal rulemaking would "proceduralize" rulemaking by making more of it take place under procedures which can be ignored only at the risk of adverse legal consequences on review. This would give more influence to those at the working level of rulemaking, both in the agency and in industry, who actually execute those procedures. Rules would stand or fall on the basis of the data, reasoning and arguments which they chose to emphasize when the rule was being made. Since these groups tend to be most familiar with the detailed technical questions involved, this seems a welcome development in itself. ${ }^{145}$

The procedural reforms required by Portland Cement and its progeny are largely aimed at improving the logic and coherence of agency rulemaking, thus making judicial review easier. The administrative record is not mentioned. Nevertheless, the nature of the record will be affected by these reforms, and in a way that underlines their beneficial effect. Indeed, the guidelines laid down by Judge Leventhal would address the way the documentation behind a rule is assembled and organized more directly than anything which EPA, at least, has issued to date. ${ }^{140}$

To the extent that the spirit of these opinions is followed, even a record assembled on a historical basis would include an increasing "procedural" component. If more and more of the work of rulemak-

issues of fact, law, or discretion presented on the record." 5 U.S.C. $\$ 557$ (c) (Supp. III 1973). The legislative history strongly emphasizes this requirement. See Senate Judiciary Comm., supra note 12, at 210-11, 273. See also $2 \mathrm{~K}$. Davis, Administrative LAw Treatise $\$ 16.05$ (1958).

143. See, e.g., Ohio Bell Tel. Co. v. Public Util. Comm'n, 301 U.S. 292 (1936) (Cardozo, J.).

144. See Spiller v. Atcheson, T. \& S. F. Ry., 253 U.S. 117, 130 (1920); United States ex rel. Vatjatter v. Commissioner of Immigration, 273 U.S. 103, 113 (1927); Unemployment Compensation Comm'n v. Aragon, 329 U.S. 143, 155 (1946); Verkuil, supra note 28, at 236-37, 239-40.

145. Such detailed analysis of facts and arguments will not yield its full benefits, however, if it is not set within and shaped by a structure of policy choices. Judge Friendly has described at length the waste and confusion that result when those with the power to make such choices-agency heads and Congress-abdicate the responsibility to make them. See H. FRIENdLY, supra note 10.

To date this has not been a problem at EP.A. The governing statutes are so sweeping and articulated in such detail that the agency has had all it can do simply to attempt to put them into effect.

146. Furthermore, agencies are likely to adhere to legally required procedures more faithfully than to procedures which they have set up on their own for internal purposes. 
ing must be done under binding procedures prior to litigation, more of the documents in a historical record will identifiably have their origin in one of the stages of those procedures. The number of documents that simply appear for the first time when counsel reviews the agency's files after litigation has begun will be correspondingly reduced.

All this, however, is a side effect of the Portland Cement reforms sketched above. If the function of the rulemaking record is squarely faced, more can be accomplished. First, although the Portland Cement cases in effect specify categories of documents that must go into the record, they nowhere state what may not go into it. All the pressures described above, therefore, continue to ensure that if, in defending litigation, agency lawyers come across any document which they would have included in the record before Portland Cement, they will put it in anyway. This occurs even though the advantage to the agency of including documents that have not been disclosed for comment has become much less certain. In practice, the courts continue to often consider these new documents and new arguments raised by the petitioners at the litigation stage. ${ }^{147}$

\section{B. A Proposal for Reform}

What still is needed is reform aimed explicitly at assembling a focused record for agency decisionmaking which, like a trial court record, could become the record for review without further action. No inquiry would then be necessary into whether the "agency" actually had "considered" the documents in the record, or whether they passed some test of relevance, any more than this is generally done in the course of appellate review of trial court decisions.

The specific reforms I suggest follow. ${ }^{148}$ Their common aim is to move rulemaking records as far as possible toward the "procedural"

147. See pp. 71-72 \& note 127 supra. Indeed, there is some conceptual trouble with a court's declining to consider such documents so long as the record is not more clearly defined. Portland Cement arguably requires only that the most relevant central documents be disclosed during the rulemaking, and that responses be made to the most relezant public comments. Though this is a great improvement over the prior state of affairs, it is still true that what appears most relevant at the stage of judicial review may not be what appeared most relevant during the rulemaking and that parties' perceptions of what is most relevant may differ in good faith. When stch a misunderstanding arises, the impulse will be great for the court to consider the questions involved even though they were not raised in the proper manner. Thotgh a complete solution to this problem is clearly impossible, a tighter definition of the record might mitigate it substantially.

148. These reforms parallel those suggested by Hamilton, supra note 9, at 1333-36. See also Currie \& Goodman, supra note 35, at 42-48. 
end of the spectrum without reimposing the adjudicatory hearing requirements that have done so much damage in the past.

First, a rulemaking docket would be established for each proposed rule. This could consist in most cases simply of a labeled, publicly accessible file drawer. A room in agency headquarters would be set aside for these files and, most important, an adequate and organized staff assigned to keep them in order. ${ }^{149}$ Where appropriate, duplicate files might be set up in other places.

Second, at the time the rule was first proposed in the Federal Regis$t e r$, all documents which the agency decided were of central relevance to the rule would be placed in the file. To ensure that these documents actually had been critically reviewed and were not dumped in for whatever help they could give, each one would have to be discussed in the preamble to the proposed rule or in the accompanying technical support document.

Third, all public comments received during the comment period and all transcripts of hearings held concerning the proposal would likewise be placed in the comment file upon receipt by the agency.

Fourth, all documents which became available after the proposal had been published and which the agency decided were of central relevance to the rulemaking would likewise be placed in the file. If the documents were important enough, the present requirements of Portland Cement might call for an extension of the comment period, or even for the proposal of an amended rule.

Fifth, to ensure that the public comments, hearing transcripts and postproposal documents had been considered, all important issues raised in them would once again have to be discussed in the preamble to the final rule or in the accompanying technical support document.

Sixth, the final rule, with its support document, would close the file. The contents of the file would be the exclusive record for judicial review. ${ }^{150}$ Nothing that had not properly been placed in the file would be considered by the court.

149. The program offices cannot be expected to keep adcquate files. Their interest will be in getting the rule out more than in how that is done. Only a separate unit with a bureaucratic interest in the recordkeeping procedures themselves can be expected to enforce those procedures properly.

150. By foreclosing the raising of new issues and the addition of new documents to the record, this proposal and the Portland Cement cases may seem to penalize the less sophisticated among those regulated who might prefer to wait until they are directly threatened with enforcement orders before challenging rules. Viewed realistically, however, these reforms will not materially affect the high premium already awarded a regulated industry for being cohesive, well-organized and bureaucratically sophisticated.

An effective challenge to a technical regulation at whatever stage cannot be ac- 


\section{The central problem with rulemaking "records" currently certified} to the courts is that no one knows exactly what they consist of until judicial review is well under way. As shown above, this may lead either to inclusion of far more documents than are needed to understand

complished simply by sending a few thousands or tens of thousands of dollars to a Washington law firm. The industry must also be ready to generate and provide the agency with technical and economic information that bears on the rule. Thus, during the development of "effluent guidelines" for discharges of hot water from steam electric power plants, the industry filed claborate studies on (1) the cost of installing and operating cooling towers, (2) the problems of fitting them on existing power plants, and (3) the impact of their installation on the economic position of the power industry, the price of electricity and utility fuel consumption. These studies werc prepared in some cases by the industry, and in some by consulting firms especially hired for the purpose. Plainly such claborate participation in agency decisions requires a deep purse, an early decision to start spending, and a substantial existing base of data about the subjects of the rulemaking. That data, in turn, will generally exist only if the industry is either highly concentrated or is already regulated to some large degree.

By contrast, when EPA cancelled the use of such poisons as cyanide and strychnine against livestock predators, see 37 Fed. Reg. 5718 (1972), the chemical companies that make these products did not protest because only a very small part of their income was affected. None of the thousands of individual poison users-largely sheep farmersprotested either, even though by protesting they could have forced reexamination of the EPA decision in a formal adjudicatory hearing. See 7 U.S.C. $\$ 135 d(1970)$. Their daily lives were presumably too remote from the government for them to realize what might happen to them and what they could do about it.

A more active trade association could have alerted its members more quickly to what was happening. But even if a hearing had been requested, the sheep farmers would not have been able to participate anywhere near as thoroughly or as effectively as the electric power industry did where regulations affecting it were concerned. To do so they would have had to submit detailed studies of the true feeding habits of predators under different conditions and their aggregate impact on the industry, and studies of the aggregate effectiveness and actual and potential side effects of the banned poisons and any alternatives to their use. In all probability at least some of these studies would take years to complete unless a significant amount of the data were available alreadyfar longer, in other words, than any reasonable regulatory scheme could allow. Their great expense would have to be met by individual assessment of thousands of individual sheep farmers. It is hard to see how much of this could be accomplished without granting an expanded trade association or some alternative body such as the Department of Agriculture far more power over the individual livestock producer than would ever have been anticipated in the past.

Many of the regulatory programs that cause this discrimination in favor of size not only have good intentions, but good or even necessary effects. Abandonment of regulation, then, is not the answer. To some extent, smaller businesses may find a greater degree of political relief available than huge corporations are likely to. And a responsible agency, of course, should take initiatives of its own to inform such people of what is intended and what the open questions are. Beyond this, however, I belicve some tendency to favor the large and well-organized is inevitable given the increasing complexity of the problems that government addresses. There is simply no way for small producers to deal with a regulatory proposal that incorporates information and judgments going far beyond their individual ability to question without taking on some of the organized bureaucratic characteristics of the regulatory agency itself.

The reforms I suggest, then, would simply recognize this unfortunate fact and provide a more responsible forum for those who are equipped or have equipped themselves to participate in the regulatory process. Indeed, as discussed in the text below, they might provide some modest assistance to members of the regulated public by making the data on which rules are based more quickly and more publicly available. 
the rule or to exclusion of documents that have a legitimate bearing on it. Under the system I suggest, that problem would largely disappear. Both sides would be forced by the threat of adverse legal consequences ${ }^{151}$ to make their contributions to a clearly defined record while rulemaking was in process, and that record could then be sent to the court. The court would know that all the documents before it had been available to all participants in the rulemaking.

To a large extent this requirement that a binding record be established in rulemaking is simply a formal procedure for implementing the guidelines laid down in Portland Cement. Its effect should not be underestimated on that account. It is precisely the lack of such procedures that has led to the failure by the courts to appreciate and enforce the full impact of Portland Cement's rather abstractly worded requirements and the failure of the agency to focus the attention of each of its elements tightly on the material supporting a rule before that rule is promulgated. Establishment of such a procedure, by contrast, will create the only context in which the requirements of that case will be enforced in a consistent and believable way.

With a central docket, it would be possible for the first time to assign a precise though still somewhat artificial meaning to the term "considered by the agency." It could be used to describe the contents of the file, on the ground that these are the documents which the agency had a duty to consider. With the record thus limited, each office in the agency and each outside party interested in the rule could look to the file to see what the rule was based on; each would be working with the same information when it expressed its views. This common basis of discussion should make it easier to recognize which questions were still open and which had been resolved.

Similarly, the Portland Cement requirement that documents be "disclosed" can present practical problems at present. They may be disclosed to one party in interest but not to another, or disclosed to one party earlier than to another. Although this is probably inevitable in any agency that tries to operate openly and can occur even where there is no motive to favor one person over others, establishment of

151. On the agency's side, though the fear of court defeats would indecd be the ultimate motive for care in assembling the record, actual results would follow only when the reforms suggested were incorporated into the bureaucratic outlook and procedures of the agency. Most probably this would occur in stages. At first, the General Counsel's office would take the lead in explaining and, where necessary, enforcing the new procedures. Later, the new office established to keep these records would gain knowledge and authority, and would take over much of the task. Finally, the program offices themselves would learn what was required and the need for outside monitoring of their performance would decrease. 
a central file at least would provide a check by setting up a minimum measure of information made available to the public generally.

Finally, if such reforms were adopted courts might be more willing than they have been to enforce the rule suggested in Portland Cement that points must be raised before the agency if they are to be raised during judicial review. The lack of coherence and definition of the present rulemaking system makes courts reluctant to do this in practice, though they may be well aware of the good reasons for it in principle..$^{152}$

\section{The Use of A Discovery System in Rulemaking}

A main goal of the reforms suggested above is to make records shorter and more organized. If under the proposed procedures the agency alone were allowed to determine which of its internal documents would be included, that achievement would be easy. In all likelihood, the reforms would allow exclusion of the mass of peripheral material-letters, working drafts, trip reports and the like-for whose exclusion there seems at present no principled basis.

152. Some practical problems with such an approach can be foresecn, but they do not appear to rise to the level of serious objections to it. To take one cxample, the scientific or technical documents which the agency includes in the record when rulemaking begins (which I will call "first ticr documents") will often cite and in part rel) on many other less centrally relevant documents ("second tier documents"), which in turn will cite to and rely on others ("third tier documents"), and so forth. Presumably only the first tier documents will be included in the administrative record. Yet even if a conscientious effort is made to put all the most important documents in this category, comments may well focus on a second or third tier document in particular cases. When this happens, should reproposal be required simply because that document was not originally part of the administrative record, ex en though later comment revealed it was probably important enough to have been included? I see no reason for such a rule.

All the second and third ticr documents will presumably be publicly available, and the mere fact of their direct or indirect citation in the first tier documents should be enough to put interested parties on notice of their relevance. If comments centered on such a document, then it should be added to any record certified to a reviewing court. But there would be no policy reason for a reproposal.

Different questions would arise where, in promulgating a rule, the agency wanted to rely on conclusions reached in a prior rulemaking. How deeply and in what manner should the factual support for that prior rule be probed? In some cases judicial review of the prior rule will simply not be available, either because it can only be challenged in a different forum or because the time limit for secking review has lapsed. But where the court has jurisdiction, some probing of that prior rule should be undertaken, though there might well be a stronger presumption of its validity if it had survived and been relied on for a number of years. If that prior rule was promulgated through use of an administrative docket system such as is suggested here, the relevant file should simply be cross-referenced. If it wasn't, the record for the new rule should contain or reference material relevant to the old one. The courts already appear to be following roughly this course. Compare the discussion of EPA's "Appendix J" method for calculating necessary reductions in hydrocarbon emissions in Texas v. EP.A, 499 F.2d 289, 294-95, 297-301 (5th Cir. 1974), with South Terminal Corp. v. EPA, 504 F.2d 646, 662 n.20 (1st Cir. 1974) (judicial review of the underlying rule held precluded because limited by statute to D.C. Circuit). 
But the judgment here cannot be left entirely to the agency. First, the availability of the Freedom of Information Act prevents it. Second, if it were, there could be no assurance that the agency would voluntarily include material adverse to its position, especially where the material contained unpalatable facts and discussions of policy, or embarrassing revelations of agency motives. This latter problem can be dealt with if the FOIA, already used in rulemaking to some extent, is used as the cornerstone of a more elaborate procedure for discovery during the rulemaking proceeding prior to judicial review. ${ }^{153}$

The mechanics of such a system could be simple. While considering a rule, the agency would stand ready to make available all material in its possession that might be thought relevant to the proposed rule, as long as its disclosure was required by the Freedom of Information Act. In addition, at the time a rule was proposed, the agency would include a limited amount of material in the record. Any person who thought that additional material should be in the record could then submit it as part of their comments on the proposal. Since all definitions of the record agree that such comments are part of it, the material would be automatically included. By the same token, if such a system were formally established, the agency would be in a much stronger position to resist belated demands to supplement the record from those who had slept on their rights during the rulemaking.

As a practical matter, at least in EPA rulemaking, voluntary compliance with requests to disclose would probably be adequate to substantially protect the interests of the industry. The same factors which cause the agency to include everything in historical records at present would cause it to make full disclosure to the industry during rulemaking. ${ }^{154}$

Although the present ad hoc system generally has resulted in a satisfactory degree of disclosure, the adoption of a more formal procedure for creating rulemaking records offers a good opportunity to adopt a system of discovery which is more explicit and predictable. In addition, the increased legal significance of timely access to documents under the proposed system arguably entitles interested persons

153. There is no constitutional requirement that opportunity for discovery be afforded the regulated parties in agency proceedings. See Friendly, supra note 26, at 1279-95. Nor does Portland Cement require onc, for it only forbids the basing of rules on data which, in "critical degree" has not been disclosed for comment. 486 F.2d at 393 .

On the other hand, EP.t, in common with most federal regulatory agencies, has statutory information gathering powers that can easily be used for "discovery" in rule-

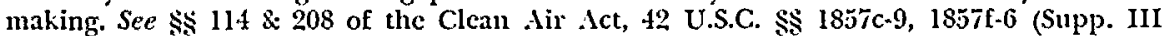
1973 ) and $\$ 308$ of the Federal Water Pollution Control Act, 33 U.S.C. $\$ 1318$ (Supp. III 1973).

154. See pp. 60-69 supra. 
to a guarantee of such access whether the agency consents or not. The question then becomes whether the Freedom of Information Act is capable of forcing the agency to make timely disclosures of damaging. material in all cases. To the extent that the FOIA is incapable of forcing disclosure, further limitations on the power of agencies would be an appropriate supplement to the proceduralization of rulemaking. records.

\section{A. Limilations of the Freedom of Information Act}

The FOIA is incapable of ensuring adequate discovery in two regards: scope of discovery and timeliness of discovery. At present the scope of FOIA discovery is limited by the $\$ 5$ exemption from disclosure for "inter-agency or intra-agency memorandums or letters which would not be available by law to a party other than an agency in litigation with the agency." 15 s The legislative history and cases make clear that this provision was meant to encourage "frank discussion of legal or policy matters in writing" by preserving the confidentiality of papers concerning them. ${ }^{156}$ Even the purely factual portions of such documents may be withheld as integral parts of the discussion of policy when the same factual information is available elsewhere. ${ }^{15 \pi}$

This exemption for agency memoranda is closely related to the bar announced in Morgan against probing the mental processes of administrative agencies. Indeed, that the language "memorandums ... which would not be available by law to a party other than an agency in litigation with the agency" is the measure of the FOIA $\$ 5$ exemption, in effect builds the "mental processes" bar into that statute. A court which does not consider probing mental processes part of its reviewing task will hardly read such language as requiring disclosure of documents for solely that purpose. ${ }^{158}$ The bad faith or improper conduct exception to the protection afforded by Morgan in judicial review has not yet been read into the $\S 5$ exemption. ${ }^{50}$ Even if the

155. 5 U.S.C. $\$ 552(b)(5)(1970)$.

156. S. REP. No. 813 , 89th Cong., 1st Sess. 9 (1965), quoted in El.1 v. Mink, t10 U.S. 73,87 (1973).

157. See Montrose Chem. Corp. v. Train, 49 I F.2d 63 (D.C. Cir. 1974). Previous cases had a somewhat different emphasis. See EP.t v. Mink, 410 U.S. 73, 91 (1973); Sterling Drug, Inc. v. FTC, 450 F.2d 698, 704 (D.C. Cir. 1971); Soucic v. David, 448 F.2d 1067, 1079 (D.C. Cir. 1971 ).

158. See KFG Nat'l Management Corp. v. NLRB, $497 \mathrm{~F} .2 \mathrm{~d} 298,305$ and cases cited at n.11 (2d Cir. 1974); Montrose Chem. Corp. v. Train, 491 F.2d 63, 69.70 (D.C. Cir. 1974).

159. The reference to disclosure in litigation in $\$ 5$ has been read to describe only what would be disclosed to a "typical" litigant, not one presenting such special circumstances. See NLRB v. Sears, Roebuck \& Co., 95 S. Ct. 1504, 1516 n.16 (1975). 
industry could make some sort of showing of agency bad faith without first seeing the damaging documents, $\S \mathbf{5}$ on its face would still allow the agency to refuse to disclose the documents if it chose to do so.

Since EPA rarely invokes the $\$ 5$ exemption, a drastic reduction in the exemption's scope and in the potential it affords for the suppression of documents would have no significant adverse effect on the agency. If no other course were available, a complete repeal of the $\$ 5$ exemption would do more good than harm. The inhibiting effect which this would have on communication within the agency would not be great. Uncertainty about the scope of the $\$ 5$ exemption and the willingness of the agency to invoke it already keeps most potentially embarrassing communications out of print. Yet I am hesitant to recommend this as the best solution. In reexamining and reforming the scope of disclosure required by the FOIA and agency policy, it may be possible to provide some confidentiality to the unformed and speculative ideas out of which good ones often grow. That the absence of a guarantee of confidentiality at present may inhibit the expression of ideas within the agency is no argument for continuing that effect in the new discovery system if a way to avoid it without unfairly suppressing information can be devised.

Although I would prefer to preserve a small exemption from FOIA disclosure requirements for documents reflecting the early and tentative stages of formulating, criticizing or reworking rules, any bright line way to accomplish it escapes me. One possible approach-about which I am not at all confident-might be to take advantage of the fact that ideas and arguments are usually formulated within discrete bureaucratic units in an agency. Only a document which leaves its unit of origin can have an effect on policy, and by the time it leaves, it will probably have been fairly well thought through. This suggests that if the agency were divided along functional lines, and all documents that crossed those lines disclosed automatically, maximum disclosure of policy proposals could be combined with minimum inhibition of their preparation. ${ }^{160}$

The second and less important inadequacy in the present use of the FOIA as a discovery device in informal rulemaking is its failure to guarantee that documents will be disclosed soon enough to allow the submission of meaningful comments. With binding records and the present discovery system an agency might be able to deny the industry an opportunity to thoroughly evaluate the support for a given

160. Such a disclosure policy would probably work toward forcing agencies to develop and adhere to guidelines for their more discretionary actions as Professor Davis has suggested. See K. Davis, Discretionary Justice 97-116 (1969). 
rule by keeping secret its deliberations in formulating the rule. Assuming that the attempt were successful, the industry could not file its FOIA request for disclosure until the notice appeared in the Federal Register. Even if the agency did not exhaust FOIA time limits or force the industry to litigate the request, the 90 day comment period typically allowed would end before the industry could prepare an adequate response to most technical rules and their supporting data.

The mechanism for solving this problem, however, already exists. Although at present comment periods are typically no longer than 90 days, the APA requires that interested persons be extended the "opportunity" to comment. ${ }^{101}$ If a system of binding records were adopted and an agency attempted to avoid meaningful adverse comment as described above, the courts could find that a 90 day comment period did not actually constitute such an opportunity ${ }^{102}$ and require much longer periods for comment after the proposal. ${ }^{163}$ One choice for the agency then would simply be to provide a much longer comment period initially. If that course would cause undue delay, preproposal disclosure policies could be adopted to make shorter formal comment periods adequate. The agency might regularly publish a list of new documents or of the rules being considered by the working groups. The agency might even start a preliminary file of centrally relevant documents in the docket room prior to making the proposal and publish notice of the opening of the file. This would provide definitive assurance that such documents had been generally available for comment and not just to those sophisticated and rvell-connected enough to learn of their existence and ask for them.

\section{B. Administrative Discovery and the Nature of the Rulemaking Record}

Establishment of an open discovery system would make it possible for records under the new procedures to grow almost as long as they do at present. All that would be needed is for the industry lawyer to resubmit as comments all the documents raked out of the agency during discovery. Even granting this potential, however, the record would still be easier to work with than at present. If the agency had done its job, the record would fall naturally into two parts. The first, com-

161. 5 U.S.C. $\$ 553$ (c) (Supp. III 1973).

162. The same principles which require the disclosure of the agency's data, methodology and reasoning could readily be held to require disclosure under circumstances which permit meaningful adverse comment. See p. 75 supra.

163. In revicwing rules promulgated without an adequate opportunity for comment, this would be accomplished by requiring a reproposal of the rule and an additional comment period. 
piled in large part by the agency itself, would contain the central factual data and analysis supporting the rule, and public comments addressed to that material. The second, submitted by industry, would consist essentially of material offered to raise doubts about the agency's good faith or competence.

Unless the industry lawyer sought to create a large record for its own sake, the sum of the two parts would be much smaller than current records. At present the acceptance of a historical approach to rulemaking records has in effect placed the burden on the agency to prove a negative-that there was an absence of bad faith and irresponsible risk assessment during the formulation of the rule by the agency. Under the proposed system for the creation of a rulemaking record, the industry could not depend upon the agency's fear of being accused of distorting the historical record to cause the inclusion of these documents. The industry would have had an opportunity to seek FOIA disclosure and to include these documents itself during the rulemaking. When judicial review began, the record would be closed. Therefore, under the new system disclosure of the peripheral documents would be sought by the industry before final rule promulgation. The only reason why the industry would include such documents in the record would be to support an affirmative industry comment that bad faith or irresponsible decisionmaking was present. There would be no reason for the industry to include the documents showing an absence of these defects which the agency includes at present.

If the regulated industries routinely made assertions of bad faith which were only marginally valid, some useless inclusions of documents might occur nevertheless. Similarly, an industry might try to impugn an agency's policy judgment not on the merits but by attempting to show that the way it was developed internally was irresponsible. As a practical matter, however, this poses no significant threat of undermining the benefits which the proposed system would generate. Courts cannot be expected to be very sympathetic to arguments alleging bad faith unless they at least appear to have substantial support. Similarly, if an agency's statement of reasons for a rule has survived both passage through the procedures described above and the substantive comments of the regulated industry, courts will not be eager to examine in additional detail how the rule arose within the agency. Concern for their own work loads, for the agency's autonomy, and respect for a limited scope of review will reduce their willingness to probe too deeply here. For these reasons, documents in the second stage of the record will probably be looked over rather quickly to see if any serious doubts are raised. Knowing this, it may 
well seem prudent for industry counsel to refrain from submitting material which, fairly viewed, does not present substantial support for their client's position, so as to avoid irritating the court with a mass of peripheral material. But for such a selflimiting course to be followed, the documents must first be disclosed. ${ }^{164}$

\section{Conclusion}

The legal system is still struggling to adjust to the greatly increased importance of informal rulemaking. The old notions that such rules are scarcely subject to judicial review and that the right to a formal hearing must accompany any significant agency action have for all practical purposes been abandoned. Instead, agencies tend to use a number of carefully selected formal procedures in informal rulemaking itself.

To date, however, these procedures have not fully succeeded in creating an alternative structure for administrative action which can provide a satisfactory framework both for agency decisions and for judicial review. The center of any such structure-the record on which both agency decisions and judicial review should be based-has been largely overlooked. The time has come to adopt procedures for rulemaking in which a formal record plays a central role. What is needed is a set of rules for compiling an informal rulemaking record during the period prior to the adoption of the rule that will also be the record for judicial review. The adoption of this change would make rulemaking a more efficient and less arbitrary method for government policymaking.

164. See South Terminal Corp. v. EPA, 504 F.2d 646 (1st Cir. 1975). In this case, involving the Boston transportation control plan, one petitioner claimed a portion of the plan was the fruit of a political deal between the Regional Administrator of EPA and the Governor of Massachusetts struck before public comments were received. EPA then made full disclosure of its written communications with the state during the period in question, which contained no evidence of such an agreement. Though the petitioners did not drop their argument, neither did they request any of the disclosed documents to be included in the record. Against this background, the court displayed a notable lack of interest in the charge. See id. at 675. 


\section{The Yale Law Journal}

Volume 85, Number 1, November 1975

\author{
JoHN W. SPIEgel \\ Editor-in-Chief \\ Edward R. MulLer \\ Managing Editor \\ MARC L. BRowN \\ JOSEPH ISENBERGH \\ EDWARd D. KLEINBARD \\ Glen A. REed \\ Article \& Book Review \\ Editors
}

\author{
Ruth N. Glushien \\ Executive Editor \\ MAdeleine A. KleINER \\ Note \& Project Editor \\ WALTER P. Loughlin \\ Thomas H. Milch \\ GLENN M. REITER \\ Michael E. Robinson \\ JefFrey L. Schulte \\ Note Editors
}

LoN S. BabBY

Donald N. Bersoff

Daniel H. Bookin

Charles G. Buschiman

FrankLin D. ChU

Benjamin I. Cohien
KeIth P. Ellison Peter Feuerle

Carl W. Herstein

Mark D. Hoffer

Peter R. Jarvis

RichaRd A. JOHNSON
TERRY S. Kogan

Paul C. Lembesis

Carlos E. MÉndez-Peñate

STEPHEN E. Roth

JoNathan W. STILL

BATE C. TOMrS III

Secretaries to the Editors M. Olive Butrerfield, Pamela Wrllmotr

\section{Student Contributors to This Issue}

Lon S. Babby, Aliens' Right to Teach: Political Socialization and the Public Schools

Peter Feuerle, Rule 34(c) and Discovery of Nonparty Land

Keith P. Ellison, Prejudicial Publicity in Trials of Public Officials 